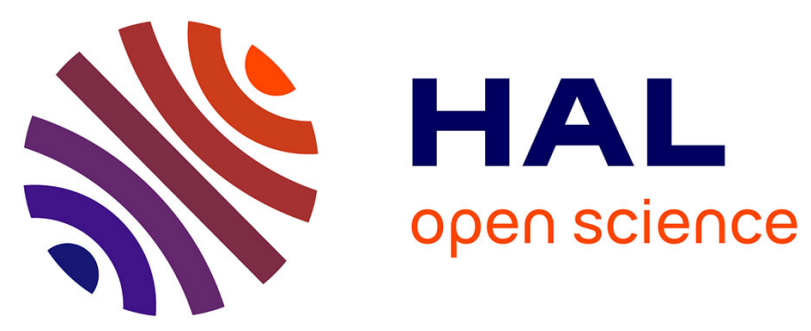

\title{
Gas-phase Titration of C7H9+ Ion Mixtures by FT-ICR Mass Spectrometry: Semiquantitative Determination of Ion Populations Generated by CI-induced Protonation of C7H8 Isomers and by EI-induced Fragmentation of Some Monoterpene
}

Michael Mormann, Jean-Yves Salpin, Dietmar Kuck

\section{To cite this version:}

Michael Mormann, Jean-Yves Salpin, Dietmar Kuck. Gas-phase Titration of C7H9+ Ion Mixtures by FT-ICR Mass Spectrometry: Semiquantitative Determination of Ion Populations Generated by CI-induced Protonation of C7H8 Isomers and by EI-induced Fragmentation of Some Monoterpene. International Journal of Mass Spectrometry, 2006, 249-250, pp.340-352. 10.1016/j.ijms.2005.12.003 . hal-00068641

\section{HAL Id: hal-00068641 https://hal.science/hal-00068641}

Submitted on 8 Oct 2018

HAL is a multi-disciplinary open access archive for the deposit and dissemination of scientific research documents, whether they are published or not. The documents may come from teaching and research institutions in France or abroad, or from public or private research centers.
L'archive ouverte pluridisciplinaire HAL, est destinée au dépôt et à la diffusion de documents scientifiques de niveau recherche, publiés ou non, émanant des établissements d'enseignement et de recherche français ou étrangers, des laboratoires publics ou privés. 


\title{
Gas-phase Titration of $\mathrm{C}_{7} \mathrm{H}_{9}{ }^{+}$Ion Mixtures by FT-ICR Mass Spectrometry: Semiquantitative Determination of Ion Populations Generated by $\mathrm{Cl}$-induced Protonation of $\mathrm{C}_{7} \mathrm{H}_{8}$ Isomers and by El-induced Fragmentation of Some Monoterpenes
}

\author{
Michael Mormann ${ }^{1,2}$, Jean-Yves Salpin ${ }^{1,3}$ and Dietmar Kuck ${ }^{1 \star}$ \\ Fakultät für Chemie, Universität Bielefeld, \\ Universitätsstrasse 25, D-33615 Bielefeld, Germany
}

In memoriam Chava Lifshitz

Correspondence to:

D. Kuck, Department of Chemistry, University of Bielefeld, D-33615 Bielefeld, Germany.

E-mail: dietmar.kuck@uni-bielefeld.de

Prof. Dr. Dietmar Kuck

Fakultät für Chemie

Universität Bielefeld

Postfach 100131

D-33501 Bielefeld, Germany

Telephone (+49) 521 106-2060

Facsimile (+49) 521 106-6417

2 Present address:

Institute for Medical Physics and Biophysics

University of Münster

Robert-Koch-Str. 31

D-48149 Münster, Germany

${ }^{3}$ Present address:

UMR CNRS 8587 "Analyse et environnement"

Bâtiment Maupertuis

Université d'Évry Val d'Essonne

Boulevard François Mitterrand

F-91025 Évry CEDEX, France 
Abstract: The composition of various mixtures of isomeric gaseous $\mathrm{C}_{7} \mathrm{H}_{9}{ }^{+}$ions, generated from four different $\mathrm{C}_{7} \mathrm{H}_{8}$ precursors by $\mathrm{Cl}$ (methane) and $\mathrm{Cl}($ isobutane) and by El-induced fragmentation of two monoterpenes, $\alpha$-pinene (5) and limonene (6), in the external ion source of an FT-ICR mass spectrometer, has been detected by means of proton transfer reactions to selected bases ("gas-phase titration") within the ICR cell. Protonation of toluene (1) was found to give a uniform $\mathrm{C}_{7} \mathrm{H}_{9}{ }^{+}$ion population containing exclusively the toluenium ions $[\mathbf{1}+\mathrm{H}]^{+}$under both $\mathrm{Cl}$ conditions. By contrast, protonation of 1,3,5-cycloheptatriene (2), 2,5-norbornadiene (3) and 6-methylfulvene (4) was found to give mixtures of constitutionally isomeric $\mathrm{C}_{7} \mathrm{H}_{9}{ }^{+}$ions, containing ions [1 $+\mathrm{H}]^{+}$and protonated 6-methylfulvene, $[4+\mathrm{H}]^{+}$, in all of the cases. Protonated norbornadiene, $\left[\mathbf{3}^{\prime}+\mathrm{H}\right]^{+}$, was detected only in minor amounts by $\mathrm{Cl}\left(\mathrm{CH}_{4}\right)$ of 2 and by $\mathrm{Cl}$ of the neutral precursor, 3, itself. Protonation of 6-methylfulvene (4) by $\mathrm{Cl}\left(\mathrm{CH}_{4}\right)$ gave rise to partial isomerization to ions $[\mathbf{1}+\mathrm{H}]^{+}$only, but $\mathrm{Cl}\left(i-\mathrm{C}_{4} \mathrm{H}_{10}\right)$ of 4 generated also protonated cycloheptatriene, $[2+\mathrm{H}]^{+}$. Both of the $\mathrm{C}_{7} \mathrm{H}_{9}{ }^{+}$ion mixtures formed by El-induced fragmentation of $\alpha$-pinene (5) and limonene (6) were found to consist mainly $(\geq 85 \%)$ of toluenium ions, $[1+\mathrm{H}]^{+}$, with only very small fractions $(\leq 10 \%)$ of dihydrotropylium ions, $[2+\mathrm{H}]^{+}$, in contrast to previous reports in the literature. The gas-phase titration experiments of the $\mathrm{C}_{7} \mathrm{H}_{9}{ }^{+}$ mixtures was found to reflect the relative thermodynamic stabilities of the constitutional $\mathrm{C}_{7} \mathrm{H}_{9}{ }^{+}$isomers and the exothermicity of the proton transfer step. The results are also discussed in view of the energy hypersurface of the isomeric $\mathrm{C}_{7} \mathrm{H}_{9}{ }^{+}$ions, parts of which have been calculated by ab-initio methods [MP2(full)/6-311+G(3df,2p)//MP2(full)/6-31G(d)]. 
Keywords: Carbenium ions; Arenium ions; Olefins (protonation of); Monoterpenes; Proton transfer reactions; Ion/molecule reactions; ion mixture analysis; Proton-induced isomerization.

\section{Introduction}

In view of the overwhelming interest in the complex behavior of the carbocations $\mathrm{C}_{7} \mathrm{H}_{8}{ }^{\cdot+}\left(\mathrm{m} / \mathrm{z}\right.$ 92) and $\mathrm{C}_{7} \mathrm{H}_{7}{ }^{+}(\mathrm{m} / \mathrm{z}$ 91) [1-7], the gas-phase chemistry of protonated toluene $\left(\mathrm{C}_{7} \mathrm{H}_{9}+, \mathrm{m} / z\right.$ 93), an apparently similar prototypical ion of organic mass spectrometry, have been a somewhat neglected subject since its beginnings in the 1960's [8]. In fact, the formation of the $\mathrm{C}_{7} \mathrm{H}_{7}{ }^{+}$ions, and their isomerization and fragmentation has been established as a prototypical example of gas-phase ion chemistry and the energetics and dynamics of the benzyl and tropylium ions, in particular, have been understood in great detail now $[7,9,10]$. Similarly, albeit less familiar because of their radical cationic nature, the gas-phase chemistry of $\mathrm{C}_{7} \mathrm{H}_{8}{ }^{\circ+}$ ions generated from toluene, cycloheptatriene and other precursors including the higher alkylbenzenes has been elaborated in depth $[4,7,11,12]$. In both cases, studies on the composition of mixtures of isomeric ions, as a function of their ways of generation, represent classical contributions to the progress of gas-phase ion chemistry over the past four decades [13].

By contrast, the manifold of the $\mathrm{C}_{7} \mathrm{H}_{9}{ }^{+}$ions' gas-phase chemistry remained less elucidated for several decades $[8,14-16]$. This is remarkable not 
only because of the formal relationship of these $\mathrm{m} / \mathrm{z} 93$ ions to the $\mathrm{m} / \mathrm{z} 91$ and $\mathrm{m} / \mathrm{z} 92$ carbocations, but also in view of the fact that the $\mathrm{C}_{7} \mathrm{H}_{9}{ }^{+}$ions have been observed very early as the major fragment ions formed upon electron ionization (EI) of terpenes or by reaction of $\mathrm{O}_{2}{ }^{+}$ions with terpenes by charge-exchange reactions, as illustrated in Figure 1 [17-20]. Moreover, $\mathrm{C}_{7} \mathrm{H}_{9}{ }^{+}$ions generated from toluene constitute prototypical alkylbenzenium ions [7, 21] and thus interconnect organic mass spectrometry to one of the major classical fields of organic chemistry, viz., electrophilic aromatic substitution [22-24].

Figure 1

However, in addition to early studies on gaseous toluenium ions, which were mostly focussed on the thermochemistry of tautomeric $\mathrm{C}_{6} \mathrm{H}_{6} \mathrm{CH}_{3}{ }^{+}$ions [25] and their peculiar unimolecular fragmentation by $\mathrm{H}_{2}$ [14] and $\mathrm{CH}_{4}$ loss [16], several more recent investigations have shed light on the energetics and unimolecular isomerization and fragmentation of the $\mathrm{C}_{6} \mathrm{H}_{6} \mathrm{CH}_{3}{ }^{+}$and related arenium ions [26]. For example, the gas-phase basicities (GB) and proton affinities (PA) of 1,3,5-cycloheptatriene [27] and 6-methylfulvene [28] have been determined, adding to the corresponding data of toluene and 2,5-norbornadiene published previously $[10,29,30]$. Furthermore, various recent experimental and computational work, including mostly the homologues and analogues of $\mathrm{C}_{7} \mathrm{H}_{9}{ }^{+}$ ions, including benzenium [31,32] and the xylenium ions [33-35] and protonated alkylcycloheptatrienes [36] have provided much insight into the parameters 
governing the unimolecular isomerization and fragmentation of these evenelectron carbocations.

Chart 1

It has been shown that the structures of different isomeric gaseous species can be probed by use of ion/molecule reactions [3,4,37]. Several studies have demonstrated the applicability of this method for the discrimination of isomeric protonated hydrocarbons mainly by proton transfer reactions [38]. In the present report, we describe the results of our gas-phase titration study of various mixtures of $\mathrm{C}_{7} \mathrm{H}_{9}{ }^{+}$ions, which were generated by gas-phase protonation of four $\mathrm{C}_{7} \mathrm{H}_{8}$ hydrocarbons (Chart 1 ) by chemical ionization $(\mathrm{Cl})$, toluene (1), 1,3,5-cycloheptatriene (2), 2,5-norbornadiene (3) and 6-methylfulvene (4) in the external ion source of an FT-ICR mass spectrometer under progessively harsher $\mathrm{Cl}$ conditions. Partial or complete deprotonation of the various $\mathrm{C}_{7} \mathrm{H}_{9}{ }^{+}$ ion mixtures thus produced by use of selected bases provided semi-quantitative information on the relative amounts of isomeric $\mathrm{C}_{7} \mathrm{H}_{9}{ }^{+}$ions, to which the gross structures of toluenium ions $\left([1+\mathrm{H}]^{+}\right)$, protonated cycloheptatriene or its (slightly more stable) valence isomer, protonated norcaradiene $\left(\left[2^{\prime}+\mathrm{H}\right]^{+}\right)[27]$, protonated 2,5-norbornadiene [29] or a valence isomer, i.e. tricyclo[1.1.1.0]hept2yl cations, $\left(\left[\mathbf{3}^{\prime}+\mathrm{H}^{+}\right)\right.$, and protonated 6-methylfulvene $\left([4+\mathrm{H}]^{+}\right)$were assigned. In addition, we performed the corresponding gas-phase titration experiments also with mixtures of $\mathrm{C}_{7} \mathrm{H}_{9}{ }^{+}$ions generated by El-induced fragmentation of two monoterpenes, viz., limonene (5) and $\alpha$-pinene (6), in the 
external ion source of the same FT-ICR instrument. The results were found to reflect the different ease of the isomeric $\mathrm{C}_{7} \mathrm{H}_{9}{ }^{+}$ions to undergo skeletal rearrangement prior to deprotonation and in dependence of the exothermicity of the protonation reaction, in line with their different thermodynamic stabilities. Also, they shed new light on the structural identity of the long-lived $\mathrm{C}_{7} \mathrm{H}_{9}{ }^{+}$ions that give rise to the $\mathrm{m} / \mathrm{z} 93$ peak in the El mass spectra of the monoterpenes.

\section{Experimental}

Materials. Toluene (1), 1,3,5-cycloheptariene (2), and 2,5-norbornadiene (3) and all liquid reference bases were distilled through a $20 \mathrm{~cm}$ Vigreux column prior to use. Purities were checked by GC/MS analysis and found to be $>99 \%$. The terpenes a-pinene (5), (R)-limonene or (S)-limonene (6) were purchased from Aldrich (Taufkirchen, Germany) and used without further purification (stated purity 97\%) as a mixture of enantiomers (5) or as the pure enantiomers. Both $(R)-6$ and $(S)-6$ were measured for the sake of reproducibility and found to give the same results. Methane (Linde, Wiesbaden, Germany, stated purity > 99.9\%) and isobutane (Linde, Wiesbaden, Germany, stated purity > 99.5\%) were used as purchased.

Methylfulvene (4) was prepared as reported previously [39, 40]. Briefly, condensation of cyclopentadiene and dimethylformamide diethyl acetal gave 6(dimethylamino)fulvene. This compound was treated with methyllithium to yield a Mannich base which was submitted to chromatography on alumina to yield 6 by reductive elimination. The identity and purity of 6 were checked by ${ }^{1} \mathrm{H}$ and 
${ }^{13} \mathrm{C}$ NMR spectroscopy (Bruker DRX 500, 500 and $126 \mathrm{MHz}$, respectively) and by El mass spectrometry (Fisons Autospec, double-focusing E/B/E sector-field instrument), by use of a heated septum inlet (acceleration voltage of $8 \mathrm{kV}$, electron energy of $70 \mathrm{eV}$, emission current of $200 \mu \mathrm{A}$, ion-source temperature $\left.160 \pm 10^{\circ} \mathrm{C}\right)$

Kinetic measurements. Ion/molecule reactions were performed by use of a Bruker Spectrospin CMS 47X FT-ICR mass spectrometer equipped with a 4.7 T superconducting magnet, an external ion source [41] and an "Infinity Cell" [42]. The protonated molecules were generated in the external ion source by chemical ionization $(\mathrm{Cl})$, using either methane or isobutane as the reagent gas. Typical ion-source conditions were: Filament current 3.5-4.0 A, electron energy $30 \mathrm{eV}$ and ionizing pulse duration $100 \mathrm{~ms}$. Generation of the $\mathrm{C}_{7} \mathrm{H}_{9}{ }^{+}$ions from the monoterpenes was achieved by electron ionization (50 eV). Ions formed in the source were transferred into the ICR cell and isolated by standard ejection procedures to remove all ions except those of interest, i.e. $\mathrm{C}_{7} \mathrm{H}_{9}{ }^{+}$, by a broad band rf pulse and a series of rf pulses with the cyclotron frequency close to that of $\left[\mathrm{C}_{7} \mathrm{H}_{9}\right]^{+}$("single shots"), in order to prevent unintended excitation. Subsequently, the ions were kinetically cooled by application of several argon pulses [43] using a magnetic valve. After a delay of $1.5 \mathrm{~s}$, during which the cooling gas was essentially removed from the cell, single shots were applied again to remove fragment ions formed by collision-induced dissociation during the cooling procedure. The residual ions were allowed to react during variable reaction time intervals $(\mathrm{t})$ with the neutral reference bases $\mathbf{B}$ (7-10) present in 
the cell at constant background pressures of $1.0-10 \times 10^{-8} \mathrm{mbar}$. The pressure readings of the ionization gauge close to the turbopump of the FT-ICR cell were calibrated by rate measurements of the reaction $\mathrm{NH}_{3}{ }^{\cdot+}+\mathrm{NH}_{3} \rightarrow \mathrm{NH}_{4}{ }^{+}+\mathrm{NH}_{2}{ }_{2}$ [44]. The differences in the sensitivities of the ionization gauge towards the various organic compounds were corrected by taking into account their polarizabilities $[45,46]$. The intensities of the signals of the ions observed were determined after Gauss multiplication of the time domain signal, followed by Fourier transformation in the frequency domain. The bimolecular rate constants for the observed proton transfer reactions from the carbenium ion under study, $[\mathrm{M}+\mathrm{H}]^{+}$, to the reference base were derived from the first order exponential decay (Eqn (1)) of the plot of the experimental intensities versus the reaction time $t$, where $k_{\text {obs }}$ is the observed pseudo-first order rate constant and $[N]$ the density number of the neutral reference bases $\mathbf{B}$ within the ICR cell. In cases where the superposition of two or more distinct proton transfer processes were observed, a linear combination of two first order exponential decay function was applied to the fitting procedure.

$$
\begin{gathered}
\frac{\left[[\mathrm{M}+\mathrm{H}]^{+}\right]_{\mathrm{t}}}{\left[[\mathrm{M}+\mathrm{H}]^{+}\right]_{\mathrm{t}=0}}=\exp \left(-\mathrm{k}_{\text {obs }} \mathrm{t}\right)=\exp \left(-\mathrm{k}_{\exp }[\mathrm{N}] \mathrm{t}\right) \\
\text { eff } \mathrm{H}^{+}=\frac{\mathrm{k}_{\text {exp }}}{\mathrm{k}_{\text {coll }}}
\end{gathered}
$$

The reaction efficiencies for a particular proton transfer process eff $\mathrm{H}^{+}$ were calculated according to Eqn 2. Herein, Kexp is the experimental rate constant and $\mathrm{k}_{\text {coll }}$ the theoretical rate constant of the respective ion/molecule 
reaction. The latter values were calculated on the basis of the trajectory model established by Su and Chesnavich [47]. The dipole moments of the neutral species were taken from the literature [48] and the respective polarizabilities were calculated according to the literature data [45].

\section{Computational details}

Ab-initio molecular orbital calculations were carried out using the Gaussian-98 set of programs [49]. The different structures were first optimized at the Hartree-Fock (HF) level with the d-polarized 6-31G(d) basis set. Harmonic frequencies were determined at this level in order to characterize stationary points as minima (equilibrium structures) or saddle points (transition

structures); these frequencies were then scaled by a factor of 0.9135 to estimate the zero-point vibrational energies [50]. Improved geometries were subsequently obtained through calculations using correlated wave functions at the second order Møller-Plesset perturbation theory, all electrons being considered for the correlation. Finally, the MP2(full)/6-31G(d) geometries were utilized in single point electronic energy calculations using the $6-311+G(3 d f, 2 p)$ extended basis set. Throughout this report, total energies are expressed in hartree and relative energies in $\mathrm{kJ} \mathrm{mol}^{-1}$. Unless otherwise noted, the relative energies given are those obtained from MP2(full)/6-311+G(3df,2p)//MP2(full)/6$31 G(d)$ total energies, and corrected for zero point vibrational energies (ZPE). Additional information containing all optimized geometries of the structures mentioned in this report are available as a supplementary material. 


\section{Results and Discussion}

Gas-phase basicities and choice of deprotonation bases. As the gasphase basicities of the four $\mathrm{C}_{7} \mathrm{H}_{8}$ isomers 1-4 are well known, suitable bases were selected in order to selectively deprotonate one or several of the conjugate acid isomers, $[\mathbf{1}+\mathrm{H}]^{+}$to $[\mathbf{4}+\mathrm{H}]^{+}$from the mixtures of $\mathrm{C}_{7} \mathrm{H}_{9}{ }^{+}$ions. Within the series of $\mathrm{C}_{7} \mathrm{H}_{8}$ isomers, toluene is the by far least basic hydrocarbon, $\mathrm{GB}(\mathbf{1})=756 \mathrm{~kJ} \mathrm{~mol}^{-1}$. By contrast, cycloheptatriene is much more basic, $\mathrm{GB}(2)$ $=798 \mathrm{~kJ} \mathrm{~mol}^{-1}$, and the gas-phase basicity of other two isomers are even beyond that value. Therefore, any of the tautomeric toluenium ions, but none of their constitutional isomers $[2+\mathrm{H}]^{+}$to $[4+\mathrm{H}]^{+}$present in the $\mathrm{C}_{7} \mathrm{H}_{9}{ }^{+}$populations, can be deprotonated by a base which has a GB similar to 1 , as it is the case with methyl formate, $\mathrm{GB}(7)=751.5 \mathrm{~kJ} \mathrm{~mol}^{-1}$, (Figure 2). By contrast, ethyl acetate, $\mathrm{GB}(\mathbf{8})=804.7 \mathrm{~kJ} \mathrm{~mol}^{-1}$, is a sufficiently strong base to remove a proton from both $[\mathbf{1}+\mathrm{H}]^{+}$and the cycloheptatriene-type isomers, such as $[\mathbf{2}+\mathrm{H}]^{+}$, whereas ions $[3+\mathrm{H}]^{+}$and $[4+\mathrm{H}]^{+}$should not react with this stronger base. However, protonated norbornadiene, $[3+\mathrm{H}]^{+}$or the more stable valence isomer tricyclo[1.1.1.0]hept-2yl cation $\left[\mathbf{3}^{\prime}+\mathrm{H}\right]^{+}$(vide infra), representing the conjugate acid of the relatively strong base, $\mathrm{GB}(3)=820 \mathrm{~kJ} \mathrm{~mol}^{-1}$, should, if present in the $\mathrm{C}_{7} \mathrm{H}_{9}{ }^{+}$populations, be deprotonated along with ions $[1+\mathrm{H}]^{+}$and $[2+\mathrm{H}]^{+}$by use of diisopropyl ether, $\mathrm{GB}(9)=828.1 \mathrm{~kJ} \mathrm{~mol}^{-1}$. Finally, protonated 6methylfulvene, having the highest gas-phase basicity of all $\mathrm{C}_{7} \mathrm{H}_{8}$ isomers studied here, $\mathrm{GB}(4)=843 \mathrm{~kJ} \mathrm{~mol}^{-1}$, is expected to be deprotonated along with 
all other $\mathrm{C}_{7} \mathrm{H}_{9}{ }^{+}$ions present in the mixtures by use of mesityl oxide [2methylpent-2-en-4-one, $\left.\mathrm{GB}(\mathbf{1 0})=846.9 \mathrm{~kJ} \mathrm{~mol}^{-1}\right]$.

Figure 2

The kinetics of the deprotonation reactions were expected to be monomodal if only one single isomer, or a mixture of easily interconverting tautomers, is present, as it should be the case for the tautomeric toluenium ions. Monomodal behaviour is also probable for ion mixtures if the basicity of the base used for deprotonation strongly exceeds the basicities of the conjugate hydrocarbons underlying the $\mathrm{C}_{7} \mathrm{H}_{9}{ }^{+}$ion mixtures. By contrast, bimodal or even trimodal kinetics are expected for cases where the basicity of the deprotonation base differs only slightly from one of the conjugate hydrocarbons. For example, deprotonation of a $\mathrm{C}_{7} \mathrm{H}_{9}{ }^{+}$ion mixture containing ions $[\mathbf{1}+\mathrm{H}]^{+}$and $[2+\mathrm{H}]^{+}$with ethyl acetate (8) should occur with high efficiency for the former fraction of ions, but with low efficiency with the fraction of the latter, and any further isomeric $\mathrm{C}_{7} \mathrm{H}_{9}{ }^{+}$ions should remain non-reactive.

$\mathrm{C}_{7} \mathrm{H}_{9}{ }^{+}$ions formed by $\mathrm{Cl}$ of toluene. A first series of experiments comprised the deprotonation of $\mathrm{C}_{7} \mathrm{H}_{9}{ }^{+}$ions generated by chemical ionization of toluene (1) in the external ion source. Two different harsh ionization conditions, $\mathrm{Cl}$ (methane) and $\mathrm{Cl}($ isobutane), were employed. The deprotonation kinetics measured with methyl formate (7) are shown in Figures $3 a$ and $3 b$, respectively. 
Figure 3

Whereas the protonation of $\mathbf{1}$ by $\mathrm{CH}_{5}{ }^{+}$in the methane plasma is a relatively exothermic process, the corresponding generation of $\mathrm{C}_{7} \mathrm{H}_{9}{ }^{+}$ions with the reagent ions of the isobutane plasma is slightly endothermic. In both cases, however, complete deprotonation of the $\mathrm{C}_{7} \mathrm{H}_{9}{ }^{+}$ion population was observed even with methyl formate as a relatively weak deprotonation base. The abundance-versus-time dependence was found to be strictly monomodal, with efficiencies eff $=0.14$ for the proton transfer from the $\mathrm{Cl}\left(\mathrm{CH}_{4}\right)$-generated $\mathrm{C}_{7} \mathrm{H}_{9}{ }^{+}$ ions and eff $=0.17$ for the proton transfer from the $\mathrm{Cl}\left(i-\mathrm{C}_{4} \mathrm{H}_{10}\right)$-generated $\mathrm{C}_{7} \mathrm{H}_{9}{ }^{+}$ ions to 7 (cf. Tables 1 and 2). Thus, the efficiencies are the same under the different $\mathrm{Cl}$ conditions used and are within the range expected. The finding that a minor fraction (ca 3\% rel. abundance) of $\mathrm{m} / \mathrm{z}=93$ ions were non-reactive is due to the presence of naturally occurring isobaric radical cations, ${ }^{13} \mathrm{C}_{1}{ }^{12} \mathrm{C}_{6} \mathrm{H}_{8}{ }^{\bullet+}$, generated by charge exchange in the $\mathrm{Cl}$ plasma or unintended El processes, respectively.

These results reflect unequivocally that the $\mathrm{C}_{7} \mathrm{H}_{9}{ }^{+}$ions that are generated from toluene in the external $\mathrm{Cl}$ source and that are transferred into the cell of the FT-ICR mass spectrometer without fragmentation ("stable ions") consist of toluenium ions exclusively; any constitutional isomers (Chart 1) are absent. However, it is conceivable that, besides the most stable para isomer, $[\mathbf{1}+\mathrm{H}]^{+}$, minor amounts of the slightly less stable ortho isomer and possibly even the considerably less stable meta isomer are present to some extent in the mixture, which is not reflected in the deprotonation kinetics due to the rapid proton ring 
walk processes within the ions and/or within the encounter complexes formed upon proton transfer.

Table 1

Table 2

$\mathrm{C}_{7} \mathrm{H}_{9}{ }^{+}$ion mixtures formed by $\mathrm{Cl}$ of 1,3,5-cycloheptatriene. When cycloheptatriene (2) was subjected to protonation under $\mathrm{Cl}$ (methane) or $\mathrm{Cl}($ isobutane) conditions, the deprotonation kinetics were found to be no longer monomodal, indicating the formation of mixtures of isomeric $\mathrm{C}_{7} \mathrm{H}_{9}{ }^{+}$ions prior to deprotonation. Protonation of 2 by $\mathrm{CH}_{5}{ }^{+}$in the methane plasma is highly exothermic $\left(\Delta \mathrm{Hr}=-287.5 \mathrm{~kJ} \mathrm{~mol}^{-1}[27,30]\right)$, and deprotonation of the $\mathrm{C}_{7} \mathrm{H}_{9}{ }^{+}$ population with the four bases 7-10 in the order of increasing gas-phase basicities revealed the presence of four constitutional $\mathrm{C}_{7} \mathrm{H}_{9}{ }^{+}$ions. Combined presentations of the deprotonation kinetics found under the two $\mathrm{Cl}$ conditions are given in Figure 4 (cf. also Tables 1 and 2).

Figure 4

When methyl formate (7) was used to deprotonate the $\mathrm{C}_{7} \mathrm{H}_{9}{ }^{+}$ions generated by $\mathrm{Cl}($ methane), a bimodal decay of the population was observed (Figure 4a). Similar to the case of toluene (1), a first-order exponential decrease was found, but about half of the $\mathrm{C}_{7} \mathrm{H}_{9}{ }^{+}$ions were found to be inert towards the base 7 , since the relative intensity of the $\mathrm{m} / \mathrm{z} 93$ signal remained constant at 
$50 \%$ of its initial value at reaction times $>15 \mathrm{~s}$. This finding suggests that about half of the $\mathrm{C}_{7} \mathrm{H}_{9}{ }^{+}$ions that were stored in the FT-ICR cell after the thermalization and isolation procedure consisted of toluenium ions, $[\mathbf{1}+\mathrm{H}]^{+}$, which are sufficiently acidic to transfer a proton to methyl formate $\mathbf{7}$, being a relatively weak base. In turn, the other half of the $\mathrm{C}_{7} \mathrm{H}_{9}{ }^{+}$ion population is not sufficiently acidic. Consequently, stronger bases have to be employed to effect further deprotonation.

In fact, use of ethyl acetate (8) as the reference base further decreases the fraction of the non-reactive $\mathrm{C}_{7} \mathrm{H}_{9}{ }^{+}$ions (Figure $4 \mathrm{a}$ ). In this case, an additional $15 \%$ fraction of the ions' population is deprotonated, indicating the presence of the second-most acidic groups of $\mathrm{C}_{7} \mathrm{H}_{9}{ }^{+}$isomers, viz. dihydrotropylium ions $[2+\mathrm{H}]^{+}$. The deprotonation kinetics with 8 as a base is trimodal; it reflects a combination of two exponential decays and the remainder fraction of non-reactive ions $\mathrm{C}_{7} \mathrm{H}_{9}{ }^{+}$ions in a relative abundance of ca. $35 \%$ of the initial value (Figure 5). Deprotonations of the two reactive fractions of $\mathrm{C}_{7} \mathrm{H}_{9}{ }^{+}$ ions have different efficiencies: The exothermic proton transfer from the toluenium ions, $[\mathbf{1}+\mathrm{H}]^{+}$, were found to occur with eff $1=0.6$, whereas the nearly thermoneutral reaction of the dihydrotropylium ions, $[2+\mathrm{H}]^{+}$, takes place with eff $=0.15$ only .

Figure 5

Deprotonation of the $\mathrm{Cl}\left(\mathrm{CH}_{4}\right)$-generated $\mathrm{C}_{7} \mathrm{H}_{9}{ }^{+}$ion mixture by use of diisopropyl ether (9) gives rise to a similar decay as that found with ethyl 
acetate (8) (Figure 4a). Again, the course of the decay curve is trimodal, but in this case the non-reactive ions represent a slightly lower fraction of $30 \%$ of the initial population. This can be taken as a hint to the presence of a minor amount (ca 5\%) of tricyclo[1.1.1.0]hept-2-yl cations, $\left[3^{\prime}+\mathrm{H}^{+}\right.$, which is slightly more acidic than ions $[2+\mathrm{H}]^{+}$. Finally, and as expected, use of mesityl oxide as the base leads to complete deprotonation of the $\mathrm{C}_{7} \mathrm{H}_{9}{ }^{+}$ion mixture. As a consequence, the least acidic component of the mixture of isomeric ions can be assigned the structure of the 6-methylfulvenium ions, $[4+\mathrm{H}]^{+}$, amounting to ca $30 \%$ of the initial overall population.

The analogous series of deprotonation experiments starting from $\mathrm{C}_{7} \mathrm{H}_{9}{ }^{+}$ ions generated by $\mathrm{Cl}($ isobutane) of cycloheptatriene (2) yielded a similarly complex result. However, owing to the considerably lower exothermicity of the protonation by the $t-\mathrm{C}_{4} \mathrm{H}_{9}{ }^{+}$ions $\left(\Delta \mathrm{H}_{\mathrm{r}}=-28.9 \mathrm{~kJ} \mathrm{~mol}^{-1}[27,30]\right)$, the composition of the $\mathrm{C}_{7} \mathrm{H}_{9}{ }^{+}$ion mixture produced was found to reflect less skeletal isomerization. As illustrated in Figure $4 \mathrm{~b}$, the fraction of the most acidic toluenium ions, $[\mathbf{1}+\mathrm{H}]^{+}$, being the most acidic set of isomers, amounts to only $20 \%$ here. The largest fraction of the $\mathrm{C}_{7} \mathrm{H}_{9}{ }^{+}$ions was deprotonated by both ethyl acetate (8) and diisopropyl ether (9), in addition to those being deprotonated by methyl formate (7) only. Clearly, this fraction, amounting to ca $60 \%$, consists of dihydrotropylium ions $[2+\mathrm{H}]^{+}$, which survived the relatively mild $\mathrm{Cl}$ process without skeletal rearrangement. The almost identical course of the deprotonation with the two differently basic reagents, $\mathbf{8}$ and $\mathbf{9}$, indicates that, in this case, isomers corresponding to protonated norbornadiene, $[3+\mathrm{H}]^{+}$, were not formed. Also, only a small fraction (ca 20\%) of methylfulvenium ions was 
found in the $\mathrm{Cl}\left(i-\mathrm{C}_{4} \mathrm{H}_{10}\right)$-generated population of $\mathrm{C}_{7} \mathrm{H}_{9}{ }^{+}$ions, when complete deprotonation was carried out by use of mesityl oxide (10). Thus, the relatively small amount of excess energy transferred during the protonation of cycloheptatriene 2 in the $\mathrm{Cl}$ (isobutane) plasma gives rise to about $40 \%$ of skeletal rearrangement of the originally formed ions $[2+\mathrm{H}]^{+}$, half of this fraction being the most stable toluenium ions, $[1+\mathrm{H}]^{+}$, the other half being the less stable methylfulvenium ions, $[4+\mathrm{H}]^{+}$. The barrier towards isomerization to protonated norbornadiene or the isomeric tricyclo[1.1.1.0]hept-2-yl ions, [3' + $\mathrm{H}]^{+}$, appears to be too high.

$\mathrm{C}_{7} \mathrm{Hg}_{9}{ }^{+}$ion mixtures formed by $\mathrm{Cl}$ of 2,5-norbornadiene. In a further series of experiments carried out under the same reaction conditions, 2,5norbornadiene (3) was protonated and the resulting population of $\mathrm{C}_{7} \mathrm{H}_{9}{ }^{+}$ions was analyzed by gas-phase titration. This is particularly interesting since the protonated conjugate, $\left[\mathbf{3}^{\prime}+\mathrm{H}\right]^{+}$, is the thermodynamically least stable isomer among the cyclic $\mathrm{C}_{7} \mathrm{H}_{9}{ }^{+}$ions studied here. This fact is reflected from the protonation/deprotonation experiments described above, which lead to $\mathrm{C}_{7} \mathrm{H}_{9}{ }^{+}$ ion populations containing only negligible or minor amounts $(\leq 5 \%)$ of $\left[3^{\prime}+\mathrm{H}^{+}\right.$ ions. Therefore, protonation of neutral 2,5-norbornadiene (3) itself should reveal whether the protonated form, $\left[\mathbf{3}^{\prime}+\mathrm{H}^{+}\right.$, can be identified unequivocally or whether these ions undergo skeletal rearrangement to constitutional isomers upon direct generation in the $\mathrm{Cl}$ (methane) or $\mathrm{Cl}$ (isobutane) plasma (Figure 6, Tables 1 and 2). 
Figure 6

In fact, the ion/molecule reactions performed with $\mathrm{C}_{7} \mathrm{H}_{9}{ }^{+}$ions generated by protonation of 3 reveal that the conjugate acid ions, $\left[3^{\prime}+\mathrm{H}\right]^{+}$, survives the transfer from the ion source into the FT-ICR cell and the isolation and thermalization of the $\mathrm{C}_{7} \mathrm{H}_{9}{ }^{+}$ion mixture. When methane was employed as the $\mathrm{Cl}$ gas (Figure 6a), the titration experiments performed with the reference bases 710 show that ca $30 \%$ of the $\mathrm{C}_{7} \mathrm{H}_{9}{ }^{+}$ion population correspond to toluenium ions, $[1+\mathrm{H}]^{+}$. The proton transfer from these ions to methyl formate occurs with eff $=$ 0.18. Two minor fractions of ca $12-15 \%$ each correspond to dihydrotropylium ions, $[2+\mathrm{H}]^{+}$, and tricyclo[1.1.1.0]hept-2-yl ions, $\left[\mathbf{3}^{\prime}+\mathrm{H}\right]^{+}$, and the major fraction (ca 45\%) consists of protonated 6-methylfulvene, $[4+\mathrm{H}]^{+}$. The trend observed with $\mathrm{Cl}$ (methane) was found to be enhanced for the $\mathrm{C}_{7} \mathrm{H}_{9}{ }^{+}$ion mixture generated by use of isobutane as the $\mathrm{Cl}$ gas (Figure $6 \mathrm{~b}$ ). In this case, the fraction of toluenium ions, $[\mathbf{1}+\mathrm{H}]^{+}$, is reduced to ca $25 \%$ and that of the dihydrotropylium ions, $[2+\mathrm{H}]^{+}$, remains nearly constant at ca $10 \%$ of the $\mathrm{C}_{7} \mathrm{H}_{9}{ }^{+}$ ion population. However, the relative amounts of protonated norbornadiene and protonated 6-methylfulvene, $\left[4+\mathrm{H}^{+}\right.$, both increase as compared to the fractions observed upon $\mathrm{Cl}$ (methane). Obviously, the protonation conditions under $\mathrm{Cl}($ isobutane) are sufficiently mild to allow ca $20 \%$ of the tricyclo[1.1.1.0]hept-2-yl ions, $\left[\mathbf{3}^{\prime}+\mathrm{H}\right]^{+}$, to survive without skeletal isomerization. Interestingly, the 6-methylfulvenium ions, $[4+\mathrm{H}]^{+}$, represent the major fraction (ca $55 \%$ ), of the $\mathrm{C}_{7} \mathrm{H}_{9}{ }^{+}$ion population generated by mild protonation of norbornadiene. 
$\mathrm{C}_{7} \mathrm{H}_{9}{ }^{+}$ion mixtures formed by $\mathrm{Cl}$ of 6-methylfulvene. Formation of $\mathrm{C}_{7} \mathrm{H}_{9}{ }^{+}$ions from 6-methylfulvene (4) under the same $\mathrm{Cl}$ (methane) and $\mathrm{Cl}($ isobutane) conditions that were used for the experiments described above leads to somewhat simpler mixtures of ions (Figure 7, Tables 1 and 2). It appears that the extent of skeletal rearrangement of the $\mathrm{C}_{7} \mathrm{H}_{9}{ }^{+}$ions formed by protonation of $\mathbf{4}$ is significantly lower than in the cases of $\mathbf{2}$ and $\mathbf{3}$ described above.

Figure 7

The $\mathrm{C}_{7} \mathrm{H}_{9}{ }^{+}$ion population generated by $\mathrm{Cl}$ (methane) consists essentially of two fractions (Figure 7a). The toluenium ions, $[\mathbf{1}+\mathrm{H}]^{+}$, amount to ca $35 \%$ of the mixture, and the 6-methylfulvenium ions, $[4+\mathrm{H}]^{+}$, represent the dominant component (ca 65\%). This follows from the finding that all of the three bases 7-9 reduce the initial $\mathrm{C}_{7} \mathrm{H}_{9}{ }^{+}$ion population to the same relative amount. Thus, dihydrotropylium ions, $\left[2+\mathrm{H}^{+}\right.$, and tricyclo[1.1.1.0]hept-2-yl ions, $\left[3^{\prime}+\mathrm{H}\right]^{+}$, are not formed upon protonation of 4 in the $\mathrm{Cl}$ (methane) plasma. Only the strongest base, mesityl oxide (10), effects complete deprotonation, including protonated 6-methylfulvene, $[4+\mathrm{H}]^{+}$, which survived to a remarkably large extent. When milder protonation conditions were applied under $\mathrm{Cl}$ (isobutane), the fraction of $\mathrm{C}_{7} \mathrm{H}_{9}{ }^{+}$ions that do not undergo skeletal rearrangement was still higher (Figure 7b). In this case, even ca $75 \%$ of the $\mathrm{C}_{7} \mathrm{H}_{9}{ }^{+}$ions formed from 6 -methylfulvene survive as 6-methylfulvenium ions, $\left[4+\mathrm{H}^{+}\right.$. However, in contrast to the $\mathrm{C}_{7} \mathrm{H}_{9}{ }^{+}$ ion population generated by $\mathrm{Cl}$ (methane), methyl formate (7) was found to 
deprotonate a significantly smaller amount of $\mathrm{C}_{7} \mathrm{H}_{9}{ }^{+}$ions than do ethyl acetate (8) and diisopropyl ether (9). Therefore, the remainder of the ion mixture consist not only of toluenium ions, $\left[\mathbf{1}+\mathrm{H}^{+}\right.$, representing a ca $15 \%$ fraction, but also contains a small amount (ca 10\%) of dihydrotropylium ions, $[2+\mathrm{H}]^{+}$. This finding is interesting because it indicates that the activation barrier for the skeletal isomerization of $[4+\mathrm{H}]^{+}$to $[2+\mathrm{H}]^{+}$is relatively low and not much higher than that towards the isomerization to toluenium ions, $[\mathbf{1}+\mathrm{H}]^{+}$. It is also remarkable that protonated norbornadiene or tricyclo[1.1.1.0]hept-2-yl ions, [3' + $\mathrm{H}]^{+}$, were not formed by protonation of methylfulvene under either $\mathrm{Cl}$ conditions.

\section{$\mathrm{C}_{7} \mathrm{Hg}_{9}{ }^{+}$ions generated by El-induced fragmentation of monoterpenes.}

As outlined in the beginning, the $\mathrm{C}_{7} \mathrm{H}_{9}{ }^{+}$ions $(\mathrm{m} / \mathrm{z}$ 93) formed in large relative abundance by El-induced loss of $\mathrm{C}_{3} \mathrm{H}_{7}{ }^{\bullet}$ (or the successive losses of $\mathrm{CH}_{3}{ }^{\circ}$ and $\mathrm{C}_{2} \mathrm{H}_{4}$ [19]) from $\alpha$-pinene (5, cf. Figure 1), limonene (6) and other monoterpenes have been a matter of discussion with regard to their structural identity [17-19]. On the basis of the fragmentation characteristics obtained by sector-field measurements, the structure of dihydrotropylium ions, $[2+\mathrm{H}]^{+}$, was assigned to the $\mathrm{C}_{7} \mathrm{H}_{9}{ }^{+}$ions having lifetimes in the range of several microseconds. On the basis of the results obtained by gas-phase titration of the $\mathrm{C}_{7} \mathrm{H}_{9}{ }^{+}$ion populations generated in directed ways by protonation of the neutral $\mathrm{C}_{7} \mathrm{H}_{8}$ precursors, 1-4, described above, the identity and relative amounts of isomeric $\mathrm{C}_{7} \mathrm{H}_{9}{ }^{+}$ions generated from $\alpha$-pinene (5) and limonene (6) were determined under the conditions of our gas-phase titration approach (Figure 8, Tables 1 and 2). 
Figure 8

The $m / z 93$ fragment ions produced from $\alpha$-pinene, 5 (Figure 8a), and $(R)$-limonene, $(R)-6$ (Figure 8b), were found to behave identically within the limits of experimental reproducibility. Identical deprotonation characteristics were obtained for the $\mathrm{C}_{7} \mathrm{H}_{9}{ }^{+}$ion population produced from (S)-limonene, further confirming the reliability of the titration experiments. In all of these cases, the by far major fraction of $\mathrm{C}_{7} \mathrm{H}_{9}{ }^{+}$ions (ca 85\%) were found to be deprotonated by use of methyl formate (7) as the reference base. Thus, toluenium ions, $[\mathbf{1}+\mathrm{H}]^{+}$, clearly dominate the decay of the $\mathrm{C}_{7} \mathrm{H}_{9}{ }^{+}$ion population with all bases 7-10 used. The course of the deprotonation of both $\left[5-\mathrm{C}_{3} \mathrm{H}_{7}\right]^{+}$and $\left[6-\mathrm{C}_{3} \mathrm{H}_{7}\right]^{+}$ions also appears to be bimodal when ethyl acetate (8) and diisopropyl ether (9) were used; however, the relative amounts of dihydrotropylium ions, $[2+\mathrm{H}]^{+}$, can be estimated to be $\leq 10 \%$ only, and the remaining fraction of $\mathrm{C}_{7} \mathrm{H}_{9}{ }^{+}$ions can be assigned to the structures of (constitutionally isomeric) methylfulvenium ions, such as $[4+\mathrm{H}]^{+}$, amounting to $5-10 \%$ only. Here again, protonated norbornadiene, $[3+\mathrm{H}]^{+}$, or tricyclo[1.1.1.0]hept-2-yl ions, $\left[\mathbf{3}^{\prime}+\mathrm{H}\right]^{+}$, respectively, were not formed by protonation of methylfulvene under either $\mathrm{Cl}$ conditions. is not formed in detectable relative abundances.

The results obtained by gas-phase titration of the $\mathrm{C}_{7} \mathrm{H}_{9}{ }^{+}$ion population formed by El-induced fragmentation of the monoterpenes clearly demonstrate that, at least under the conditions used in these experiments, the predominating fraction consists of toluenium ions, $[\mathbf{1}+\mathrm{H}]^{+}$. This finding is a sharp contrast to the results obtained previously by charge stripping techniques, which indicated 
the greatest fraction of $\mathrm{C}_{7} \mathrm{H}_{9}{ }^{+}$ions from the monoterpenes corresponds to dihydrotropylium ions, $[2+\mathrm{H}]^{+}[19]$.

\section{Summary on the gas-phase titration experiments on $\mathrm{C}_{7} \mathrm{H}_{9}{ }^{+}$ions} generated from different precursors

The relative amounts of the four different constitutional isomers determined for the $\mathrm{C}_{7} \mathrm{H}_{9}{ }^{+}$ion populations generated from different precursors are collected in Table 1. As a first important result, it is evident that the protonation of toluene (1) does not give rise to ring-expanded or ring-contracted isomers. Thus, proton-induced skeletal rearrangements, which are known to occur with short-lived or metastable $\mathrm{C}_{7} \mathrm{H}_{9}{ }^{+}$ions, are not reflected in the ion mixtures accessible by gas-phase proton transfer reactions. Toluenium ions [ $\mathbf{1}$ $+\mathrm{H}]^{+}$ions were found exclusively, in accordance with the high activation barriers towards skeletal rearrangement known for these arenium ions. The reluctance of the extremely long-lived $\left[1+\mathrm{H}^{+}\right.$ions studied under FT-ICR conditions to undergo skeletal isomerization is not surprising and in line with previous FT-ICR experiments [51]. By contrast, the $\mathrm{C}_{7} \mathrm{H}_{9}{ }^{+}$ions generated by protonation of the cycloolefins $\mathbf{2 - 4}$ were found to isomerize preferably to toluenium ions, $[\mathbf{1}+\mathrm{H}]^{+}$, on the one hand, and to methylfulvenium ions, such as $[4+\mathrm{H}]^{+}$, on the other. This result is in accordance relatively high thermochemical stability of both of these ions, as compared to those of dihydrotropylium ions, $\left[2+\mathrm{H}^{+}\right.$, and norbornenyl cations, $\left[\mathbf{3}^{\prime}+\mathrm{H}\right]^{+}$. As a further result, and again not surprisingly, it is evident that the extent of skeletal 
isomerization clearly depends on the exothermicity of protonation. The lower the excess energy transferred to the $\mathrm{C}_{7} \mathrm{H}_{9}{ }^{+}$ions upon protonation, the higher is the content of the protonated $\mathrm{C}_{7} \mathrm{H}_{8}$ cycloolefin subjected to protonation in the $\mathrm{Cl}$ source. Thus, significant amounts of the thermodynamically least stable among the $\mathrm{C}_{7} \mathrm{H}_{9}{ }^{+}$isomers studied here, viz. protonated norbornadiene, $[3+\mathrm{H}]^{+}$, or isomeric tricyclo[1.1.1.0]hept-2-yl cations [3' $+\mathrm{H}]^{+}$were only detected when the conjugate base, the precursor $\mathbf{3}$ itself, was used as the neutral precursor.

Gas-phase titration analysis of the $\mathrm{C}_{7} \mathrm{H}_{9}{ }^{+}$ion population originating from the radical cations of the monoterpenes $\mathbf{5}$ and $\mathbf{6}$ revealed that toluenium ions, [ 1 $+\mathrm{H}^{+}$, represent the by far predominant isomers, at least under the FT-ICR conditions used in the present work. This finding is in contrast to previous reports $[18,19]$, in which the presence of major amounts of dihydrotropylium ions, $[2+\mathrm{H}]^{+}$, or of complex ion mixtures, was suggested.

\section{Calculated energy profile of $\mathrm{C}_{7} \mathrm{H}_{9}{ }^{+}$ions}

As outlined in the Introduction, the detailed energy profile of gaseous $\mathrm{C}_{7} \mathrm{H}_{9}{ }^{+}$ions has been known only in part to date $[9,10,13,27-30]$. In view of our results on the gas-phase titration of $\mathrm{C}_{7} \mathrm{H}_{9}{ }^{+}$ion mixtures presented above, and the recently published energetics obtained computationally for the analogous $\mathrm{C}_{8} \mathrm{H}_{11}{ }^{+}$ions including protonated xylene and related alkylbenzenium ions [35], we disclose the results of our ab initio calculations carried out on the isomerization of several isomeric $\mathrm{C}_{7} \mathrm{H}_{9}{ }^{+}$ions, including the tautomeric toluenium ions $[1+\mathrm{H}]^{+}$, protonated cycloheptatriene $[2+\mathrm{H}]^{+}$, protonated norbornadiene [3 
$+\mathrm{H}]^{+}$, which, upon protonation, immediately forms tricyclo[1.1.1.0]hept-2-yl cations by transannular elctrophilic attack and protonated 6-methylfulvene [4+ $\mathrm{H}^{+}$. The calculated energy profile is shown in Figure 9.

\section{Figure 9}

It is evident and in full agreement with previous results $[25,52]$ that paraprotonated toluene, $\left[1 p+\mathrm{H}^{+}\right.$, is the most stable among all of the $\mathrm{C}_{7} \mathrm{H}_{9}{ }^{+}$isomers (the "stabilomer") and that its tautomeric forms, $[10+\mathrm{H}]^{+},[1 m+\mathrm{H}]^{+}$and $[1 i+$ $\mathrm{H}^{+}$(in the mentioned order) are only slightly thermodynamically less stable. Ring contraction to 6-methylfulvenium ions, $[4+\mathrm{H}]^{+}$, via a bicyclic isomer $\left(\left[4^{\prime}+\right.\right.$ $\mathrm{H}]^{+}$in Figure 9) is endothermic by ca $39 \mathrm{~kJ} \mathrm{~mol}^{-1}$ but has to overcome barriers as high as ca $209 \mathrm{~kJ} \mathrm{~mol}^{-1}$. In accordance with recently published results on the xylenium ions [35], ring expansion of the toluenium ions to dihydrotropylium ions occurs best via the meta-tautomer, $[\mathbf{1 m}+\mathrm{H}]^{+}$, involving a 1,3-hydride shift from the methyl group to one of the ortho positions. However, this process and the subsequent formation of the bicyclic isomer, protonated norcaradiene $\left(\left[2^{\prime}+\mathrm{H}\right]^{+}\right.$ in Figure 9) [27] requires even more energy than the ring contraction, viz. ca $285 \mathrm{~kJ} \mathrm{~mol}^{-1}$. Starting from the stabilomer $\left[\mathbf{1 p}+\mathrm{H}^{+}\right.$, the formation of $\left[\mathbf{3}^{\prime}+\mathrm{H}\right]^{+}$, is calculated to be endothermic by $96.5 \mathrm{~kJ} \mathrm{~mol}^{-1}$, while a value of $+125 \mathrm{~kJ} \mathrm{~mol}^{-1}$ can be deduced from the known thermochemically data [29]. Thus, ions [3' + $\mathrm{H}]^{+}$are considered the least stable isomers among $\mathrm{C}_{7} \mathrm{H}_{9}{ }^{+}$ions studied here. In addition, the height of the isomerization barrier (TS9; 1,4 methylene shift) separating $\left[\mathbf{3}^{\prime}+\mathrm{H}\right]^{+}$ions from $\left[\mathbf{2}^{\prime}+\mathrm{H}\right]+$ species is found equal to $169 \mathrm{~kJ} \mathrm{~mol}^{-1}$ 
In line with the computational results, it is not surprising that $\mathrm{C}_{7} \mathrm{H}_{9}{ }^{+}$ions generated from toluene (1) were found to retain the constitution of their neutral precursors even under $\mathrm{Cl}$ (methane) conditions, even if proton transfer from $\mathrm{CH}_{5}{ }^{+}$is exothermic by $\Delta \mathrm{H}_{\mathrm{r}}=-241 \mathrm{~kJ} \mathrm{~mol}^{-1}$. By contrast, protonation of the three cycloolefins cycloheptatriene (2), norbornadiene (3) and 6-methylfulvene (4) by $\mathrm{CH}_{5}{ }^{+}$ions is much more exothermic, viz. $\Delta \mathrm{H}_{\mathrm{r}}=-\left(288-333\right.$ ) $\mathrm{kJ} \mathrm{mol}^{-1}$ (cf. Table 1) and the observation of various $\mathrm{C}_{7} \mathrm{H}_{9}{ }^{+}$ion mixtures indicating partial ring contraction of $[2+\mathrm{H}]^{+}$and ring expansion of $[4+\mathrm{H}]^{+}$is also in accordance with the calculated energy profile. The finding that the tricyclic valence isomer of protonated norbornadiene, $\left[\mathbf{3}^{\prime}+\mathrm{H}\right]^{+}$, represents a very minor fraction in the $\mathrm{C}_{7} \mathrm{H}_{9}{ }^{+}$ion mixture generated from 2 and is completely absent in the mixture generated by $\mathrm{Cl}\left(\mathrm{CH}_{4}\right)$ of 4 suggests that ring opening of its strained bi- (or tri)cyclic skeleton to produce six- or five-membered monocyclic isomers should be particularly facile processes associated with low activation barriers.

In view of the fact that the $\mathrm{Cl}$ (methane) plasma contains also less acidic reagent ions, such as $\mathrm{C}_{2} \mathrm{H}_{5}{ }^{+}$, and that only part of the exothermicity will be transferred to the $\mathrm{C}_{7} \mathrm{H}_{9}{ }^{+}$ions, it is obvious that a fraction of the ions' population consists of non-rearranged isomers. Thus, ions $\left[\mathbf{3}^{\prime}+\mathrm{H}\right]^{+}$, are detected even under the harsh protonation conditions of $\mathrm{Cl}$ (methane), suggesting that the activation barriers towards skeletal isomerization are not negligible.

However, this overall picture is probably not as simple as discussed above. This follows by considering the observed compositions of the $\mathrm{C}_{7} \mathrm{H}_{9}{ }^{+}$ions mixtures generated under the mild $\mathrm{Cl}($ isobutane) conditions in the light of the calculated energy profile. While the observed retention of the skeletal integrity is 
evident in the case of toluene (1), the observed skeletal rearrangements of the three cycloolefins 2, 3 and 4 upon protonation by $\mathrm{C}_{4} \mathrm{H}_{9}{ }^{+}$and even $\mathrm{C}_{3} \mathrm{H}_{7}{ }^{+}$ions ions is not in accordance with the thermochemistry shown in Table 1 and Figure 9. Protonation of cycloheptatriene (2) by $\mathrm{C}_{4} \mathrm{H}_{9}{ }^{+}$and $\mathrm{C}_{3} \mathrm{H}_{7}+$ is exothermic by only $\Delta \mathrm{H}_{\mathrm{r}}=-29$ and $-79 \mathrm{~kJ} \mathrm{~mol}^{-1}$, respectively, which is clearly not sufficient to overcome the energy barriers towards the observed ring contraction to ions [1 + $\mathrm{H}]^{+}$and $[4+\mathrm{H}]^{+}$(cf. Figure $4 b$ ). A similar argument holds for the protonation of 6-methylfulvene (4), in spite of the increased exothermicities of the proton $\operatorname{transfer}\left(\Delta \mathrm{H}_{\mathrm{r}}=-74\right.$ and $-124 \mathrm{~kJ} \mathrm{~mol}^{-1}$, respectively $)$.

Another observation pointing to the higher complexity of the scenario of cycloolefinic $\mathrm{C}_{7} \mathrm{H}_{9}{ }^{+}$ions is the finding that the titration analysis of the ion mixture generated from 6-methylfulvene (4) under $\mathrm{Cl}$ (methane) leads to two components only, viz. methylfulvenium ions, $[\mathbf{4}+\mathrm{H}]^{+}$, and toluenium ions, $[\mathbf{1}+$ $\mathrm{H}]^{+}$, whereas a ca $10 \%$ fraction of protonated cycloheptatriene, $[2+\mathrm{H}]^{+}$, was found under the milder $\mathrm{Cl}($ isobutane) conditions (Figure $7 \mathrm{~b})$. Hence, it appears that there are either additional unimolecular isomerization paths connecting, for example, the 6-methylfulvenium structures $[4+\mathrm{H}]^{+}$with the relatively less stable dihydrotropylium-type structures $[2+\mathrm{H}]^{+}$and $\left[2^{\prime}+\mathrm{H}\right]^{+}$are viable, in line with recent extended calculations of the $\mathrm{C}_{8} \mathrm{H}_{11}{ }^{+}$ions' energy hypersurface [35]. Alternatively, it appears conceivable that at least some parts of the isomerization phenomena reported here occur by more complicated mechanisms, for example, by isomerization within the bimolecular encounter complex or within an alkylation/dealkylation sequence occurring in the $\mathrm{Cl}$ plasma. The latter type of mechanism is reminiscent of the particularly facile 
ring contraction of protonated alkylcycloheptatrienes to the corresponding (higher) alkylbenzenium ions under $\mathrm{Cl}$ conditions [36a] and the complex isomerization and fragmentation behaviour of bi- and tricyclic $\mathrm{C}_{8} \mathrm{H}_{11}{ }^{+}$ions [36b].

\section{Conclusion}

The gas-phase titration experiments presented here open interesting insights into the chemistry of such complex systems like the gaseous $\mathrm{C}_{7} \mathrm{H}_{9}{ }^{+}$ions turned out to be. In fact, these systems behave much more complicated than the protonated arenes, as demonstrated by the contrasting isomerization propensity of protonated $\mathrm{C}_{7} \mathrm{H}_{8}$ cycloolefins as compared to that of protonated toluene. Nevertheless, most of the experimental findings correlate well with the relative stabilities of the $\mathrm{C}_{7} \mathrm{H}_{9}{ }^{+}$ions involved, as well as with the energy barriers towards isomerization. However, there are indications that the energy hypersurface of the $\mathrm{C}_{7} \mathrm{H}_{9}{ }^{+}$ions is certainly more complex than discussed here, in accordance with recent calculations on the related $\mathrm{C}_{8} \mathrm{H}_{11}{ }^{+}$ions [35]. Inspiration and more exact experiments are needed to master our understanding of seemingly simple gaseous carbenium ions by mass spectrometric techniques. Chava Lifshitz' lucid role and personality in this field of science will keep in our minds throughout these efforts. 
Table 1: Results of the gas-phase titration of various $\mathrm{C}_{7} \mathrm{H}_{9}{ }^{+}$ion mixtures.

\begin{tabular}{|c|c|c|c|c|c|}
\hline $\begin{array}{l}\text { Precursor } \\
\text { (method of generation) }\end{array}$ & $\begin{array}{l}\Delta H_{\mathrm{r}}^{\mathrm{a}, \mathrm{b}} \\
\text { protonation }\end{array}$ & of $[1+\mathrm{H}]^{+\mathrm{C}}$ & {$[2+\mathrm{H}]^{+\mathrm{C}}$} & {$[3+\mathrm{H}]^{+\mathrm{C}}$} & {$[4+\mathrm{H}]^{+\mathrm{C}}$} \\
\hline $1\left(\mathrm{Cl}, \mathrm{CH}_{4}\right)$ & -240.5 & 100 & - & - & - \\
\hline $1\left(\mathrm{Cl}, i-\mathrm{C}_{4} \mathrm{H}_{10}\right)$ & +18.1 & 100 & - & - & - \\
\hline $2\left(\mathrm{Cl}, \mathrm{CH}_{4}\right)$ & -287.5 & $\geq 50$ & $\leq 15$ & $\leq 6$ & $\leq 30$ \\
\hline $2\left(\mathrm{Cl}, \mathrm{i}-\mathrm{C}_{4} \mathrm{H}_{10}\right)$ & -28.9 & $\geq 21$ & $\leq 56$ & $\leq 3$ & $\leq 20$ \\
\hline $3\left(\mathrm{Cl}, \mathrm{CH}_{4}\right)$ & -305.8 & $\geq 30$ & $\leq 11$ & $\leq 12$ & $\leq 47$ \\
\hline $3\left(\mathrm{Cl}, i-\mathrm{C}_{4} \mathrm{H}_{10}\right)$ & -47.2 & $\geq 13$ & $\leq 11$ & $\leq 20$ & $\leq 56$ \\
\hline $4\left(\mathrm{Cl}, \mathrm{CH}_{4}\right)$ & -332.5 & $\geq 35$ & - & - & $\leq 65$ \\
\hline $4\left(\mathrm{Cl}, \mathrm{i}-\mathrm{C}_{4} \mathrm{H}_{10}\right)$ & -73.9 & $\geq 15$ & $\leq 10$ & - & $\leq 75$ \\
\hline $5(E I)^{d}$ & - & $\geq 88$ & $\leq 5$ & - & $\leq 6$ \\
\hline$(R)-6(E \mathrm{E})^{\mathrm{d}}$ & - & $\geq 82$ & $\leq 10$ & - & $\leq 8$ \\
\hline$(S)-6(E I)^{d}$ & - & $\geq 84$ & $\leq 7$ & - & $\leq 10$ \\
\hline
\end{tabular}

a Given in $\mathrm{kJ} \mathrm{mol}^{-1}$.

${ }^{\text {b }}$ Calculated from $\Delta H_{r}=\Delta P A$. For the proton affinities of hydrocarbons 1-4, see refs 27, 28, and 30. $P A\left(\mathrm{CH}_{4}\right)=543.5 \mathrm{~kJ} \mathrm{~mol}^{-1}[30], P A\left(i-\mathrm{C}_{4} \mathrm{H}_{8}\right)=802.1 \mathrm{~kJ} \mathrm{~mol}^{-1}$ [30].

${ }^{c}$ Given as the differences of the relative ion abundances [\%] determined in the titration experiments.

${ }^{\mathrm{d}}$ Generated under El conditions (50 eV). 
Table 2: Rate constants and deprotonation efficiencies of various $\mathrm{C}_{7} \mathrm{H}_{9}{ }^{+}$ion mixtures.

\begin{tabular}{|c|c|c|c|c|c|c|}
\hline $\begin{array}{l}\text { Precursor } \\
\text { (method of generation) }\end{array}$ & Base $\mathbf{B}^{\mathrm{a}}$ & $\mathrm{kexp}^{\mathrm{b}}$ & $\mathrm{kexp} 2^{\mathrm{b}}$ & $\mathrm{k}_{\mathrm{coll}}{ }^{\mathrm{b}, \mathrm{c}}$ & eff 1 & $e f_{2}$ \\
\hline $1\left(\mathrm{Cl}, \mathrm{CH}_{4}\right)$ & 7 & 2.35 & - & 16.77 & 0.14 & - \\
\hline $1\left(\mathrm{Cl}, \mathrm{i}-\mathrm{C}_{4} \mathrm{H}_{10}\right)$ & 7 & 2.85 & - & 16.77 & 0.17 & - \\
\hline $2\left(\mathrm{Cl}, \mathrm{CH}_{4}\right)$ & 7 & 2.52 & - & 16.77 & 0.15 & - \\
\hline $2\left(\mathrm{Cl}, \mathrm{CH}_{4}\right)$ & 8 & 10.14 & 2.54 & 16.90 & 0.60 & 0.15 \\
\hline $2\left(\mathrm{Cl}, \mathrm{CH}_{4}\right)$ & 9 & 9.41 & 2.90 & 14.48 & 0.65 & 0.2 \\
\hline $2\left(\mathrm{Cl}, \mathrm{CH}_{4}\right)$ & 10 & 15.98 & 3.19 & 22.83 & 0.7 & 0.14 \\
\hline $2\left(\mathrm{Cl}, \mathrm{i}-\mathrm{C}_{4} \mathrm{H}_{10}\right)$ & 7 & 2.18 & - & 16.77 & 0.13 & - \\
\hline $2\left(\mathrm{Cl}, \mathrm{i}-\mathrm{C}_{4} \mathrm{H}_{10}\right)$ & 8 & 13.86 & 3.21 & 16.90 & 0.82 & 0.19 \\
\hline $2\left(\mathrm{Cl}, i-\mathrm{C}_{4} \mathrm{H}_{10}\right)$ & 9 & 7.25 & 2.46 & 14.48 & 0.5 & 0.17 \\
\hline $2\left(\mathrm{Cl}, \mathrm{i}-\mathrm{C}_{4} \mathrm{H}_{10}\right)$ & 10 & 14.61 & 4.79 & 22.83 & 0.64 & 0.21 \\
\hline $3\left(\mathrm{Cl}, \mathrm{CH}_{4}\right)$ & 7 & 3.02 & - & 16.77 & 0.18 & - \\
\hline $3\left(\mathrm{Cl}, \mathrm{CH}_{4}\right)$ & 8 & 9.46 & 2.70 & 16.90 & 0.56 & 0.16 \\
\hline $3\left(\mathrm{Cl}, \mathrm{CH}_{4}\right)$ & 9 & 7.82 & 2.88 & 14.48 & 0.54 & 0.2 \\
\hline $3\left(\mathrm{Cl}, \mathrm{CH}_{4}\right)$ & 10 & 18.26 & 2.74 & 22.83 & 0.8 & 0.12 \\
\hline $3\left(\mathrm{Cl}, i-\mathrm{C}_{4} \mathrm{H}_{10}\right)$ & 7 & 2.68 & - & 16.77 & 0.16 & - \\
\hline $3\left(\mathrm{Cl}, \mathrm{i}-\mathrm{C}_{4} \mathrm{H}_{10}\right)$ & 8 & 10.82 & 1.52 & 16.90 & 0.64 & 0.09 \\
\hline $3\left(\mathrm{Cl}, \mathrm{i}-\mathrm{C}_{4} \mathrm{H}_{10}\right)$ & 9 & 11.29 & 2.04 & 14.48 & 0.78 & 0.14 \\
\hline $3\left(\mathrm{Cl}, \mathrm{i}-\mathrm{C}_{4} \mathrm{H}_{10}\right)$ & 10 & 17.81 & 4.12 & 22.83 & 0.78 & 0.18 \\
\hline $4\left(\mathrm{Cl}, \mathrm{CH}_{4}\right)$ & 7 & 3.02 & - & 16.77 & 0.18 & - \\
\hline $4\left(\mathrm{Cl}, \mathrm{CH}_{4}\right)$ & 8 & 10.14 & - & 16.90 & 0.6 & - \\
\hline $4\left(\mathrm{Cl}, \mathrm{CH}_{4}\right)$ & 9 & 9.41 & - & 14.48 & 0.65 & - \\
\hline $4\left(\mathrm{Cl}, \mathrm{CH}_{4}\right)$ & 10 & 15.99 & 3.21 & 22.83 & 0.7 & 0.14 \\
\hline $4\left(\mathrm{Cl}, \mathrm{i}-\mathrm{C}_{4} \mathrm{H}_{10}\right)$ & 7 & 2.85 & - & 16.77 & 0.17 & - \\
\hline $4\left(\mathrm{Cl}, \mathrm{i}-\mathrm{C}_{4} \mathrm{H}_{10}\right)$ & 8 & 9.46 & 2.03 & 16.90 & 0.56 & 0.12 \\
\hline $4\left(\mathrm{Cl}, \mathrm{i}-\mathrm{C}_{4} \mathrm{H}_{10}\right)$ & 9 & 8.26 & 2.75 & 14.48 & 0.57 & 0.19 \\
\hline $4\left(\mathrm{Cl}, i-\mathrm{C}_{4} \mathrm{H}_{10}\right)$ & 10 & 14.59 & 4.79 & 22.83 & 0.64 & 0.21 \\
\hline
\end{tabular}


Table 2 continued

\begin{tabular}{|c|c|c|c|c|c|c|}
\hline $\begin{array}{l}\text { Precursor } \\
\text { (method of generation) }\end{array}$ & Base $\mathbf{B}^{a}$ & $\mathrm{kexp1}^{\mathrm{b}}$ & $\mathrm{kexp} \mathrm{2}^{\mathrm{b}}$ & $\mathrm{k}_{\mathrm{coll}} \mathrm{b}^{\mathrm{b}} \mathrm{c}$ & eff 1 & eff $_{2}$ \\
\hline $5(E I)^{d}$ & 7 & 2.35 & - & 16.77 & 0.14 & - \\
\hline $5(E I)^{d}$ & 8 & 11.66 & - & 16.90 & 0.69 & - \\
\hline $5(E I)^{d}$ & 9 & 10.71 & - & 14.48 & 0.74 & - \\
\hline $5(E I)^{d}$ & 10 & 19.86 & 4.34 & 22.83 & 0.87 & 0.19 \\
\hline$(R)-6(E I)^{d}$ & 7 & 2.85 & - & 16.77 & 0.17 & - \\
\hline$(R)-6(E I)^{d}$ & 8 & 9.80 & - & 16.90 & 0.58 & - \\
\hline$(R)-6(E I)^{d}$ & 9 & 10.86 & - & 14.48 & 0.75 & - \\
\hline$(R)-6(E I)^{d}$ & 10 & 2.98 & 2.97 & 22.83 & 0.72 & 0.13 \\
\hline$(S)-6(E I)^{d}$ & 7 & 3.35 & - & 16.77 & 0.2 & - \\
\hline$(S)-6(E I)^{d}$ & 8 & 10.15 & - & 16.90 & 0.6 & - \\
\hline$(S)-6(E I)^{d}$ & 9 & 10.57 & - & 14.48 & 0.73 & - \\
\hline$(S)-6(E I)^{d}$ & 10 & 16.89 & 3.43 & 22.83 & 0.74 & 0.15 \\
\hline
\end{tabular}

${ }^{a}$ For the gas-phase basicities of the reference bases 7-10, see ref. 30.

${ }^{b}$ Values $\times 10^{-10} \mathrm{~cm}^{3}$ molecule ${ }^{-1} \mathrm{~s}^{-1}$.

${ }^{c}$ Calculated according to ref. 47.

${ }^{\mathrm{d}}$ Generated under El conditions (50 eV). 
Table 3: Calculated total energies (Hartree), relative energies and ZPE (kJ $\mathrm{mol}^{-1}$ ) of species involved in the various isomerization processes

\begin{tabular}{cccc}
\hline Species & MP2(full)/6-311+G(3df,2p)//MP2(full)/6-31G(d) & ZPE ${ }^{a}$ & $\Delta \mathrm{E}^{b}$ \\
\hline$[\mathbf{1} \boldsymbol{i}+\mathrm{H}]^{+}$ & -271.382603 & 358 & 35 \\
{$[\mathbf{1 0}+\mathrm{H}]^{+}$} & -271.392871 & 355 & 5 \\
{$[\mathbf{1} \boldsymbol{m}+\mathrm{H}]^{+}$} & -271.388095 & 355 & 18 \\
{$[\mathbf{1} \boldsymbol{p}+\mathrm{H}]^{+}$} & -271.394789 & 355 & 0 \\
{$[\mathbf{2}+\mathrm{H}]^{+}$} & -271.360142 & 361 & 97 \\
{$\left[\mathbf{2}^{\prime}+\mathrm{H}\right]^{+}$} & -271.367483 & 361 & 78 \\
{$\left[\mathbf{3}^{\prime}+\mathrm{H}\right]^{+}$} & -271.360698 & 362 & 97 \\
{$[\mathbf{4}+\mathrm{H}]^{+}$} & -271.380060 & 355 & 39 \\
{$\left[\mathbf{4}^{\prime}+\mathrm{H}\right]^{+}$} & -271.365711 & 357 & 78 \\
$\mathbf{A}$ & -271.367092 & 360 & 78 \\
TS1 & -271.380716 & 350 & 32 \\
TS2 & -271.380444 & 350 & 33 \\
TS3 & -271.379678 & 350 & 35 \\
TS4 & -271.314350 & 352 & 208 \\
TS5 & -271.310711 & 343 & 209 \\
TS6 & -271.284522 & 350 & 285 \\
TS7 & -271.286144 & 353 & 283 \\
TS8 & -271.330028 & 352 & 167 \\
TS9 & -271.292742 & 353 & 266 \\
\hline
\end{tabular}

a Calculated at the HF/6-31G(d) level and scaled by a factor 0.9135 .

${ }^{b} \Delta E=[E(A)-E(B)] \times 2625.5+Z P E(A)-Z P E(B)$, with $B=[1+H]^{+}$.

${ }^{c}$ From reference 27. 


\section{Acknowledgements}

DK thanks the Fonds der Chemischen Industrie for fincial support. MM gratefully acknowledges financial support by the Graduiertenförderung des Landes Nordrhein-Westfalen. JYS and DK thank the European Commission (HUCAMO; project no. CHRX-CT93 0291, "Fundamental Studies in Gas-phase Ion Chemistry and Mass Spectrometry") for support of this project.

\section{References}

1. C. Lifshitz, Y. Gotkis, A. Ioffe, J. Laskin, S. Shaik, Int. J. Mass Spectrom. Ion Processes 125 (1993) R7.

2. C. Lifshitz, Acc. Chem. Res. 27 (1994) 138.

3. D. Kuck, Mass Spectrom. Rev. 9 (1990), 181.

4. J.T. Bursey, M.M. Bursey, D.G.I. Kingston, Chem. Rev. 73 (1973) 191.

5. J.H. Moon, J.C. Choe, M.S. Kim, J. Phys. Chem. A 104 (2000) 458.

6. P.N. Rylander, S. Meyerson, H.M. Grubb, J. Am. Chem. Soc. 79 (1957) 842.

7. (a) D. Kuck, Int. J. Mass Spectrom. 213 (2002) 101. (b) D. Kuck,.in: N.M.M. Nibbering (Ed.), Encyclopedia of Mass Spectrometry, Vol. 4, Elsevier, Amsterdam, 2005, p. 270.

8. M.S.B. Munson, F.H. Fields, J. Am. Chem. Soc. 89 (1967) 1047.

9. J.L.M. Abboud, I. Alkorta, J.Z. Dávalos, P. Müller, E. Quintanilla, Adv. Phys. Org. Chem. 37 (2002) 57. 
10. (a) S.G. Lias, J.E. Bartmess, J.F. Liebman, J.L. Holmes, R.D. Levin, W.G. Mallard, J. Phys. Chem. Ref. Data 17 (1988), Suppl. No. 1, 1. (b) NIST Standard Reference Database Number 69, March 2003 Release; National Institute of Standards and Technology, Gaithersburg, MD 20899 (http://webbook.nist.gov/chemistry).

11. J. Grotemeyer, H.F. Grützmacher, Org. Mass Spectrom. 17 (1982) 353.

12. (a) Y.H. Kim, J.C. Choe, M.S. Kim, J. Phys. Chem. A 105 (2001) 5751.

(b) C. Rebrion-Rowe, T. Mostefaoui, S. Laubé, J.B.A. Mitchell, J. Chem. Phys. 113 (2000) 113, 3039. (b) M. Malow, M. Penno, K.M. Weitzel, J. Phem. Chem. A 107 (2003) 10625.

13. D. Kuck, in: N.M.M. Nibbering (Ed.), Encyclopedia of Mass Spectrometry, Vol. 4, Elsevier, Amsterdam, 2005, p. 199.

14. (a) D.H. Williams, G. Hvistendahl, J. Am. Chem. Soc. 96 (1974) 6755. (b) G. Hvistendahl, D.H. Williams, J. Chem. Soc., Perkin Trans. 2 (1975) 881.

15. (a) F. Cacace, Acc. Chem. Res. 21 (1988) 215. (b) F. Cacace, P. Giacomello, J. Chem. Soc., Perkin Trans. 2 (1978) 652.

16. D. Kuck, J. Schneider, H.F. Grützmacher, J. Chem. Soc., Perkin Trans. 2 (1985) 689.

17. D. Kuck, M. Mormann, in The Chemistry of Functional Groups: The Chemistry of Dienes and Polyenes, Vol. 2; Z. Rappoport (Ed), Wiley: New York, 2000, 1-57.

18. (a) H. Schwarz, F. Borchers, K. Levsen, Z. Naturforsch. B 31 (1976) 935.

(b) L. Friedman, A.P. Wolf, J. Am. Chem. Soc. 80 (1958) 2424. 
19. C. Basic, A.G. Harrison, Can. J. Appl. Spectrosc. 2 (1991) 33.

20. N. Schoon, C. Amelynck, L. Vereecken, E. Arijs, Int. J. Mass Spectrom. 229 (2003) 231.

21. D. Kuck, Mass Spectrom. Rev. 9 (1990) 9, 583.

22. R. Taylor, Electrophilic Aromatic Substitution; Wiley: Chichester, 1990.

23. S. Fornarini, Mass Spectrom. Rev. 15 (1996) 365. (b) S. Fornarini, M.E. Crestoni, Acc. Chem. Res. 31 (1998) 827.

24. D. Kuck, in: P.B. Armentrout (Ed.), Encyclopedia of Mass Spectrometry, Vol. 1, Elsevier, Amsterdam, 2003, p. 591.

25. J.L. Devlin, J.F. Wolf, R.W. Taft, W.J. Hehre, J. Am. Chem. Soc. 98 (1976) 1990.

26. D. Kuck, in: N.M.M. Nibbering (Ed.), Encyclopedia of Mass Spectrometry, Vol. 4, Elsevier, Amsterdam, 2005, p. 229.

27. J.Y. Salpin, M. Mormann, J. Tortajada, M.T. Nguyen, D. Kuck, Eur. J. Mass Spectrom. 9 (2003) 361.

28. M. Mormann, J.Y. Salpin, D. Kuck, Eur. J. Mass Spectrom. 5 (1999) 441.

29. R. Houriet, T. Schwitzguebel, P.A. Carrupt, P. Vogel, Tetrahedron Lett. 27 (1986) 37.

30. E.P.L. Hunter, S.G. Lias, J. Phys. Chem. Ref. Data 27 (1998) 413.

31. N. Solca, O. Dopfer, Angew. Chem. 114 (2002) 3781, Angew. Chem. Int. Ed. Engl. 41 (2002) 3628.

32. D. Schröder, J. Loos, H. Schwarz, R. Thissen, O. Dutuit, J. Phys. Chem. A 108 (2004) 9931. 
33. H.H. Büker, H.F. Grützmacher, M.E. Crestoni, A. Ricci, Int. J. Mass Spectrom. Ion Processes 160 (1997) 167.

34. M. Mormann, D. Kuck, Int. J. Mass Spectrom. 219 (2002) 497.

35. B. Arstad, S. Kolboe, O. Swang, J. Phys. Org. Chem. 17 (2004) 1023.

36. (a) M. Mormann, D. Kuck, J. Mass Spectrom. 34 (1999) 384. (b) M. Mormann, D. Kuck, Int. J. Mass Spectrom. 210/211 (2001) 531.

37. (a) J.S. Brodbelt, Mass Spectrom. Rev. 16 (1997) 91. (b) M.K. Green , C.B. Lebrilla., Mass Spectrom. Rev. 16 (1997) 53. (c) M.N. Eberlin, Mass Spectrom. Rev. 16 (1997) 113. (d) A. Filippi, A. Giardini, S. Piccirillo , M. Speranza, Int. J. Mass Spectrom. 198 (2000) 137. (e) S. Gronert, Chem. Rev. 101 (2001) 329. (f) N.M.M. Nibbering, Int. J. Mass Spectrom. 200 (2000) 27.

38. (a) S.G. Lias, P. Ausloos, J. Chem. Phys. 82 (1985) 3613. (b) H.H. Büker, H.F. Grützmacher, Int. J. Mass Spectrom. Ion Processes 109 (1991) 95. (c) J. Ni, A.G. Harrison, Can. J. Chem. 73 (1995) 1779. (d) G. Bouchoux, M.T. Nguyen, J.Y. Salpin, J. Phys. Chem. A 104 (2000) 5778. (e) G. van der Rest, P. Mourgues, D. Leblanc, H.E. Audier, Eur. Mass Spectrom. 3 (1997) 323. (f) Z.Q. Zhu, T. Gäumann, Org. Mass Spectrom. 28 (1993) 1111.

39. E. Sturm, K. Hafner, Angew. Chem. 76 (1964) 862, Angew. Chem. Int. Ed. Engl. 3 (1964) 749. (b) D.W. Macomber, W.C. Spink, M.D. Rausch, J. Organometall. Chem. 250 (1983) 311.

40. H. Meerwein, W. Florian, N. Schön, G. Stopp, Liebigs Ann. Chem. 641 (1961) 1. 
41. P. Kofel, M. Allemann, H. Kellerhals, K.-P. Wanczek, Int. J. Mass Spectrom. Ion Processes 65 (1985) 97.

42. P. Caravatti, M. Allemann, Org. Mass Spectrom. 26 (1991) 514.

43. D. Thölmann, H.F. Grützmacher, J. Am. Chem. Soc., 113 (1991) 3281.

44. N.G. Adams, D. Smith, J.F. Paulson, J. Chem. Phys. 72 (1980) 288.

45. K.J. Miller, J. Am. Chem. Soc. 112 (1990) 8543.

46. J.E. Bartmess, R.M. Georgiadis, Vacuum 33 (1983) 149.

47. T. Su, W. T. Chesnavich, J. Chem. Phys. 76 (1982) 5183.

48. (a) A.L. McClellan, Tables of Experimental Dipole Moments, Vol. 1, Freeman, San Francisco, CA, 1963. (b) A.L. McClellan, Tables of Experimental Dipole Moments, Vol. 2, Rahara Enterprises, El Cerrito, CA, 1973.

49. Gaussian 98, Revision A.7: M.J. Frisch, G.W. Trucks, H.B. Schlegel, G.E. Scuseria, M.A. Robb, J.R. Cheeseman, V.G. Zakrzewski, J.A. Montgomery, Jr., R.E. Stratmann, J.C. Burant, S. Dapprich, J.M. Millam, A.D. Daniels, K.N. Kudin, M.C. Strain, O. Farkas, J. Tomasi, V. Barone, M. Cossi, R. Cammi, B. Mennucci, C. Pomelli, C. Adamo, S. Clifford, J. Ochterski, G.A. Petersson, P.Y. Ayala, Q. Cui, K. Morokuma, D.K. Malick, A.D. Rabuck, K. Raghavachari, J.B. Foresman, J. Cioslowski, J.V. Ortiz, A.G. Baboul, B.B. Stefanov, G. Liu, A. Liashenko, P. Piskorz, I. Komaromi, R. Gomperts, R.L. Martin, D.J. Fox, T. Keith, M.A. AlLaham, C.Y. Peng, A. Nanayakkara, C. Gonzalez, M. Challacombe, P.M.W. Gill, B. Johnson, W. Chen, M.W. Wong, J.L. Andres, C. 
Gonzalez, M. Head-Gordon, E.S. Replogle, J.A. Pople, Gaussian Inc., Pittsburgh (PA), 1998.

50. A.P. Scott, L. Radom, J. Phys. Chem. 100 (1996) 16502.

51. D. Kuck, S. Ingemann, L.J. de Koning, H.F. Grützmacher, N.M.M. Nibbering, Angew. Chem. 97 (1985) 691; Angew. Chem. Int. Ed. Engl. 24 (1985) 693.

52. (a) M. Eckert-Maksić, M. Klessinger, Z.B. Maksić, Chem. Eur. J. 2 (1996) 1251; (b) Z.B. Maksić, M. Eckert-Maksić, in Theoretical and Computational Chemistry, Vol. 5 (Ed. C. Párkányi), pp. 203-231; Elsevier: Amsterdam, 1998.

\section{Captions to Figures}

Figure 1

Figure 1: El $(70 \mathrm{eV})$ mass spectrum of $\alpha$-pinene (5), obtained by use of a sector-field instrument (VG-Autospec).

Figure 2

Figure 2: Schematic representation of the gas-phase titration of a mixture of different $\mathrm{C}_{7} \mathrm{H}_{9}{ }^{+}$ions.

Figure 3

Figure 3: Deprotonation kinetics of $\mathrm{C}_{7} \mathrm{H}_{9}{ }^{+}$ion populations generated from toluene (1) by (a) $\mathrm{Cl}$ (methane) and (b) $\mathrm{Cl}$ (isobutane), as obtained by use of 
methyl formate $7\left(\mathrm{~GB}=751.5 \mathrm{~kJ} \mathrm{~mol}^{-1}\right)$. The monomodal course reflects the exclusive presence of toluenium ions $[\mathbf{1}+\mathrm{H}]^{+}$.

Figure 4

Figure 4: Deprotonation kinetics of $\mathrm{C}_{7} \mathrm{H}_{9}{ }^{+}$ion populations generated from cycloheptatriene (2) by (a) $\mathrm{Cl}$ (methane) and (b) $\mathrm{Cl}$ (isobutane) as obtained by use of four different bases, viz., methyl formate (7), ethyl acetate (8), diisopropyl ether (9), and mesityl oxide (10).

Figure 5

Figure 5: Semi-logarithmic plot of the intensity-vs-time curve of the deprotonation of the $\mathrm{C}_{7} \mathrm{H}_{9}{ }^{+}$ion population generated by $\mathrm{Cl}$ (methane) of cycloheptatriene (2), as obtained by use of ethyl acetate (8).

Figure 6

Figure 6: Deprotonation kinetics of $\mathrm{C}_{7} \mathrm{H}_{9}{ }^{+}$ion populations generated from norbornadiene (3) by (a) $\mathrm{Cl}$ (methane) and (b) $\mathrm{Cl}$ (isobutane), as obtained by use of four different bases, viz., methyl formate (7), ethyl acetate (8), diisopropyl ether (9), and mesityl oxide (10).

Figure 7

Figure 7: Deprotonation kinetics of $\mathrm{C}_{7} \mathrm{H}_{9}{ }^{+}$ion populations generated from 6methylfulvene (4) by (a) $\mathrm{Cl}$ (methane) and (b) $\mathrm{Cl}$ (isobutane), as obtained by use 
of four different bases, viz., methyl formate (7), ethyl acetate (8), diisopropyl ether (9), and mesityl oxide (10).

Figure 8

Figure 8: Deprotonation kinetics of $\mathrm{C}_{7} \mathrm{H}_{9}{ }^{+}$ion populations generated by Elinduced fragmentation of (a) $\alpha$-pinene (5) and (b) (R)-limonene $[(R)-6]$, as obtained by use of four different bases, viz., methyl formate (7), ethyl acetate (8), diisopropyl ether (9), and mesityl oxide (10).

Figure 9

Figure 9: Energy profile (in $\mathrm{kJ} \mathrm{mol}^{-1}$ ) of the interconversion of $\mathrm{C}_{7} \mathrm{H}_{9}{ }^{+}$ions, as determined by MP2(full)/6-311+G(3df,2p)//MP2(full)/6-31G(d,p)+ZPE ab initio calculations. For assignments and details, see Table 3. 


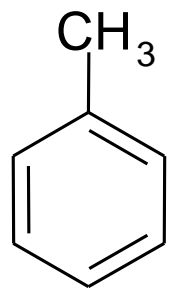

1

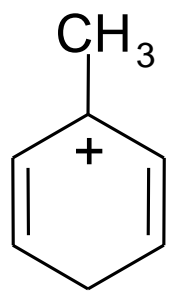

$[1+\mathrm{H}]^{+}$

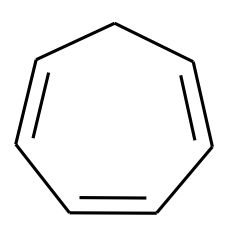

2

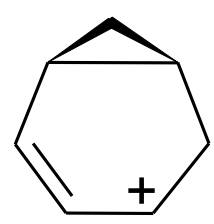

$\left[2^{\prime}+\mathrm{H}\right]^{+}$

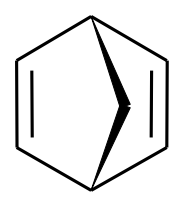

3

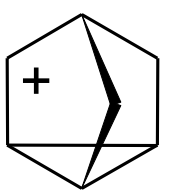

$\left[3^{\prime}+\mathrm{H}\right]^{+}$

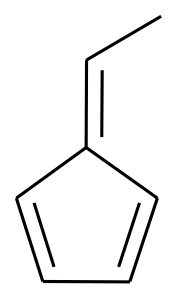

4

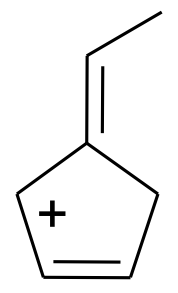

$[4+\mathrm{H}]^{+}$ 


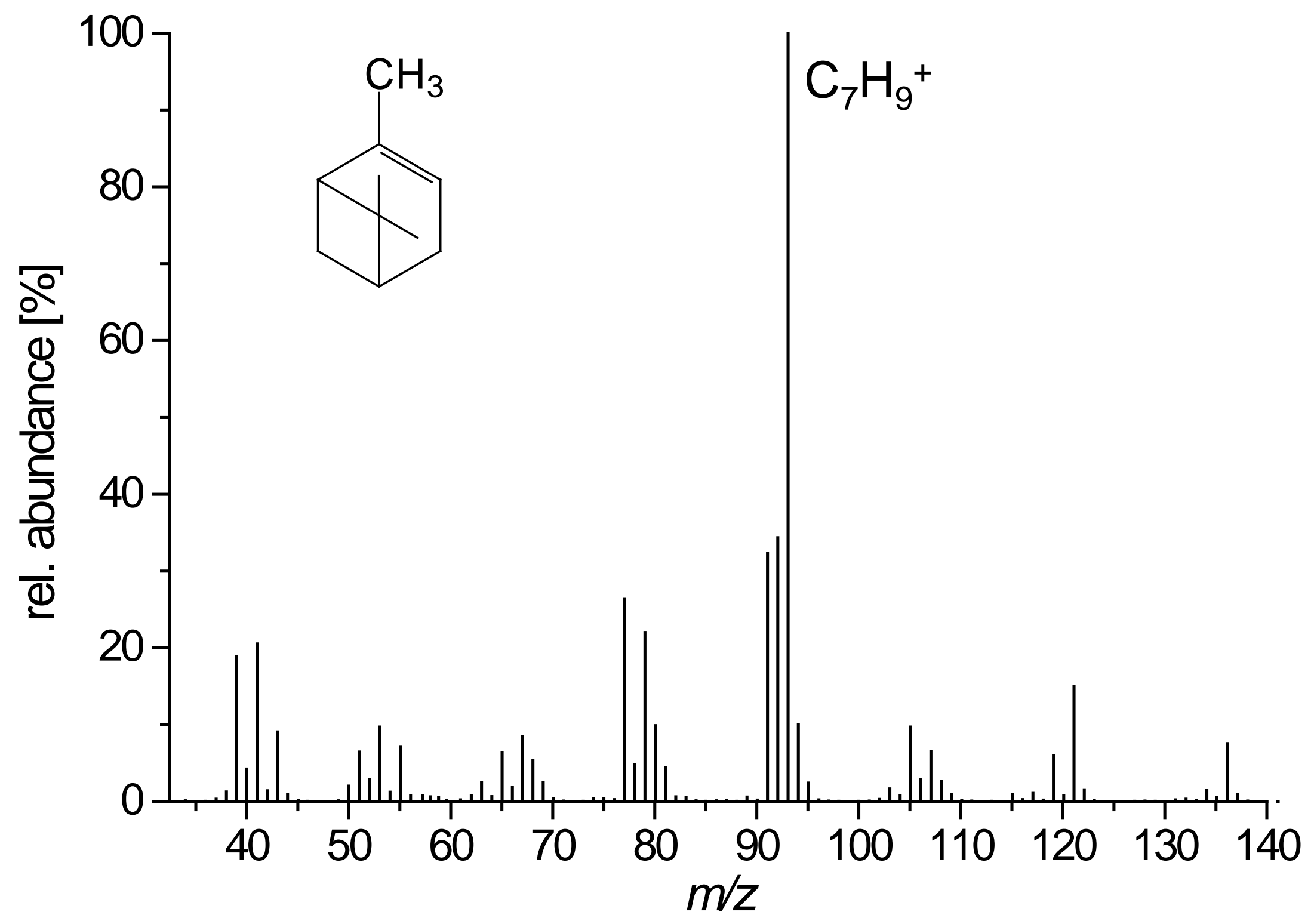

Mormann et al. Figure 1 
$\underbrace{C+i}_{H}$

$[1+\mathrm{H}]^{+}$

$756 \mathrm{~kJ} / \mathrm{mol}$

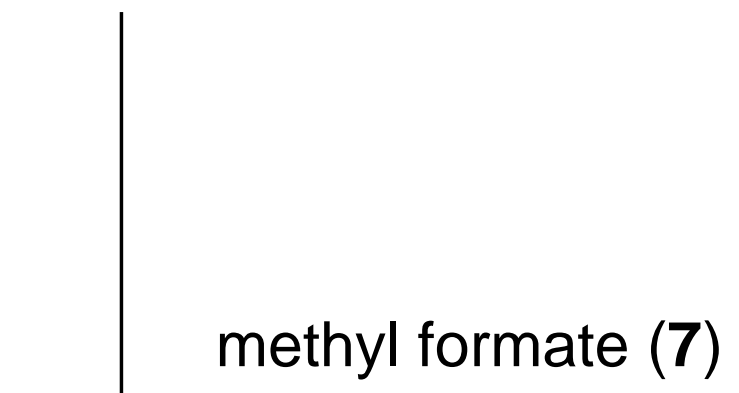

$\mathrm{GB}(7)=$

$751.5 \mathrm{~kJ} / \mathrm{mol}$

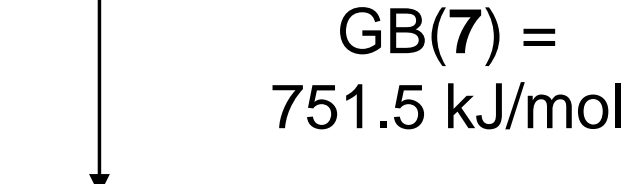

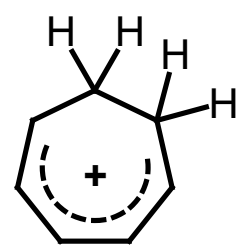

$[2+\mathrm{H}]^{+}$

$798 \mathrm{~kJ} / \mathrm{mol}$

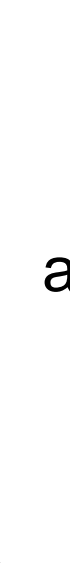

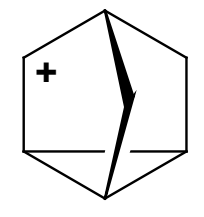

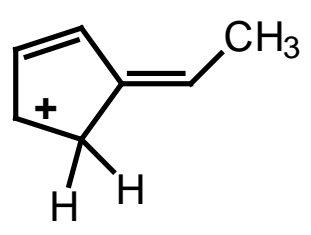

$\left[3^{\prime}+\mathrm{H}^{+}\right.$

$[4+\mathrm{H}]^{+}$

$820 \mathrm{~kJ} / \mathrm{mol} \quad 843 \mathrm{~kJ} / \mathrm{mol}$

GB of the conjugate hydrocarbon

\begin{tabular}{c|c|} 
& \\
ethyl & diisopropyl \\
acetate (8) & ether (9) \\
$\mathrm{GB}(\mathbf{8})=$ & $\mathrm{GB}(\mathbf{9})=$ \\
804.7 & 828.1 \\
$\mathrm{~kJ} / \mathrm{mol}$ & $\mathrm{kJ} / \mathrm{mol}$
\end{tabular}

mesityl oxide (10)

$\mathrm{GB}(10)=$

$846.9 \mathrm{~kJ} / \mathrm{mol}$

GB 


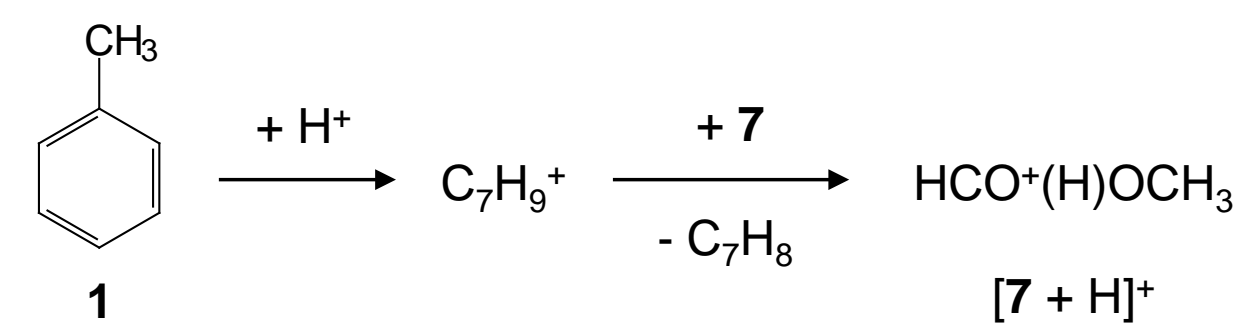

(a) $\mathrm{Cl}$ (methane)

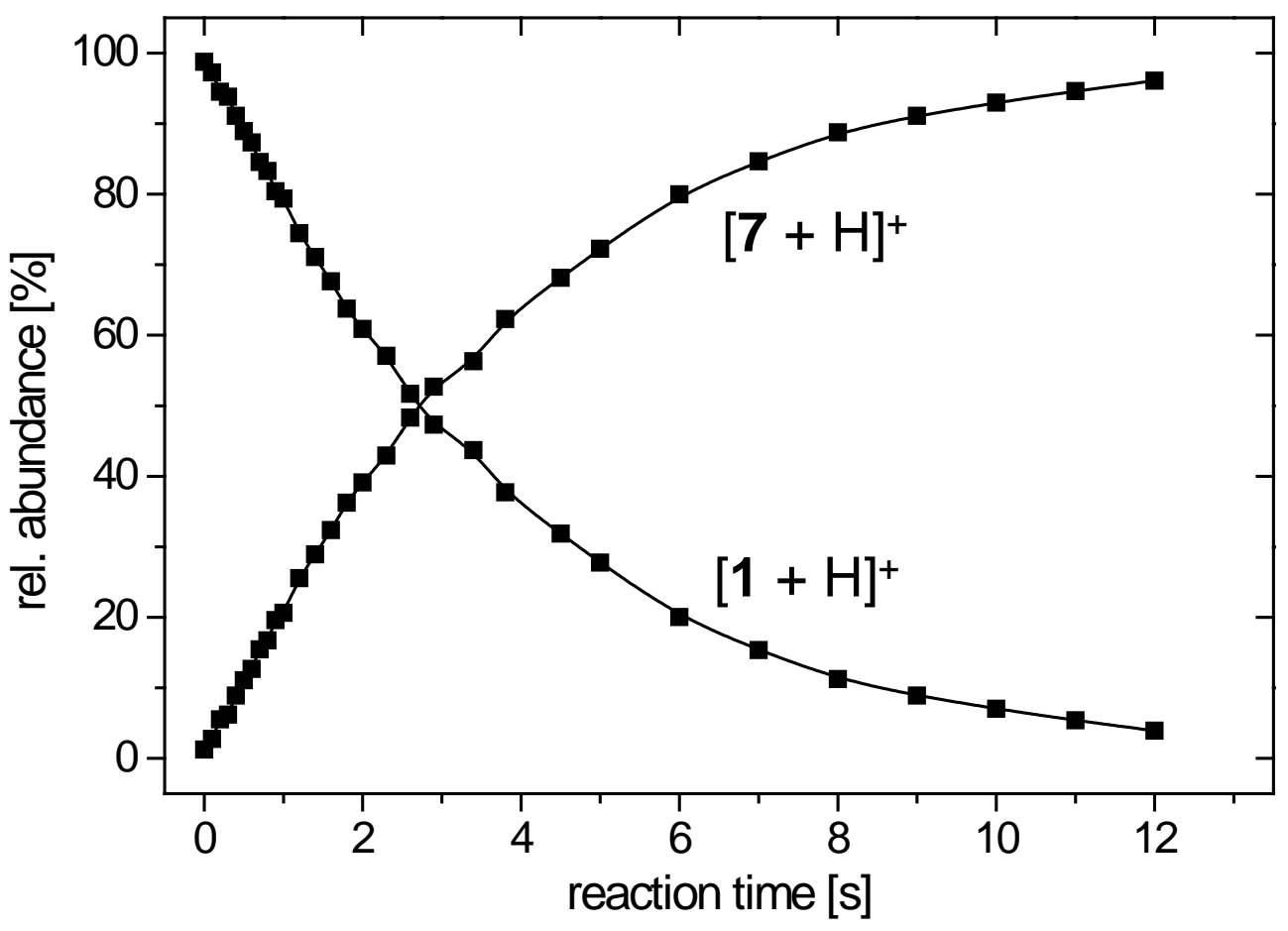

(b) $\mathrm{Cl}$ (isobutane)

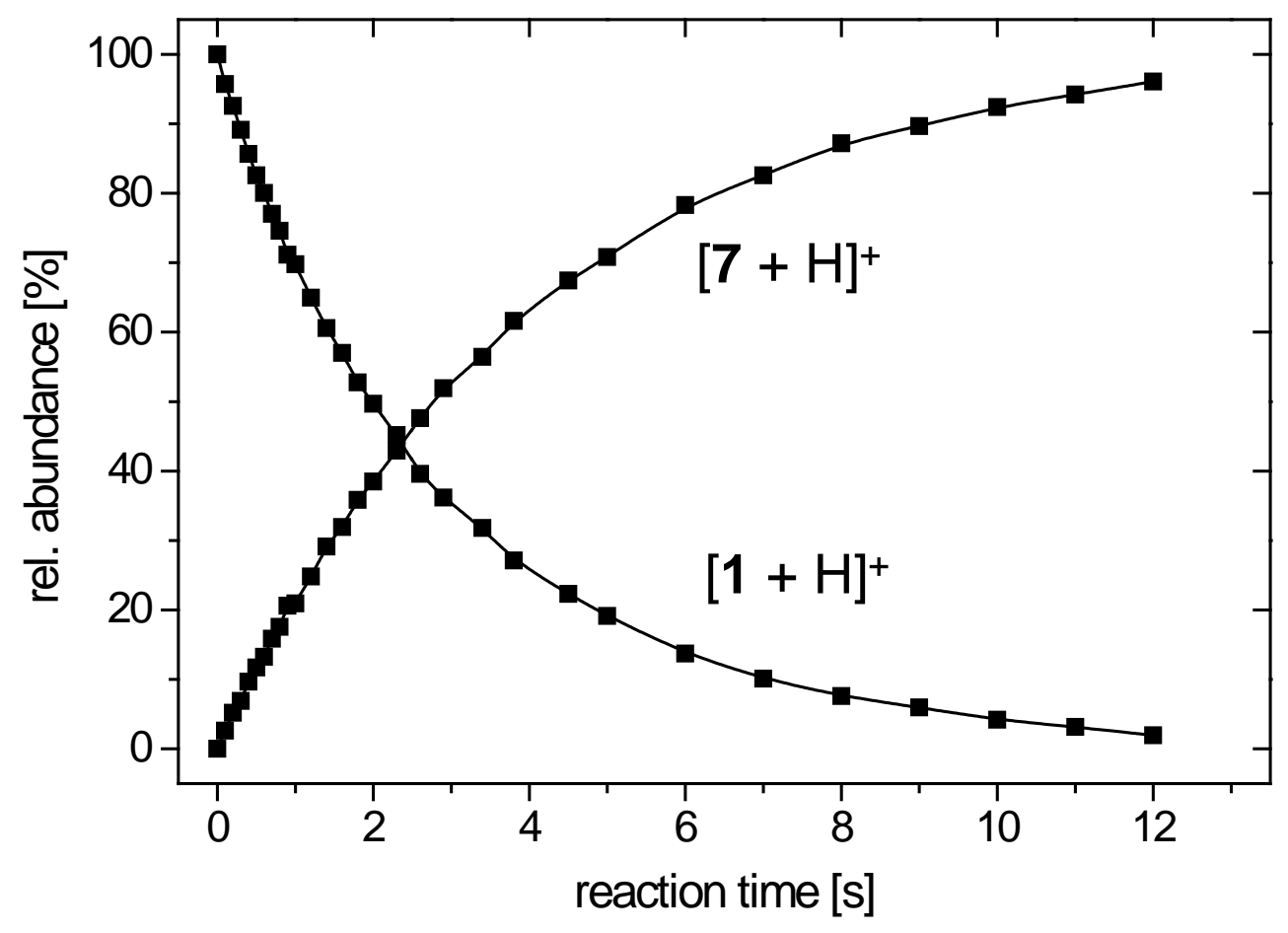



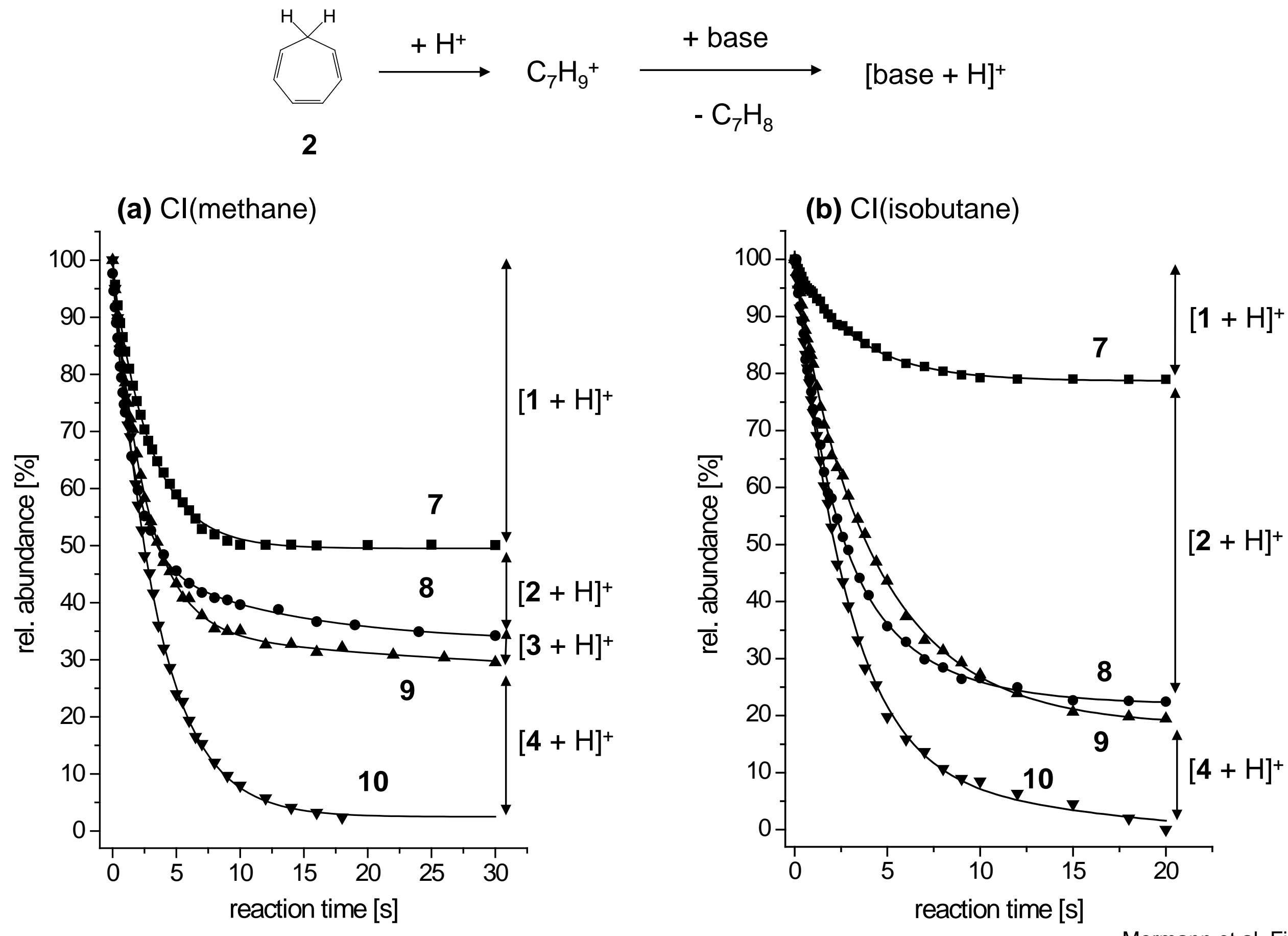


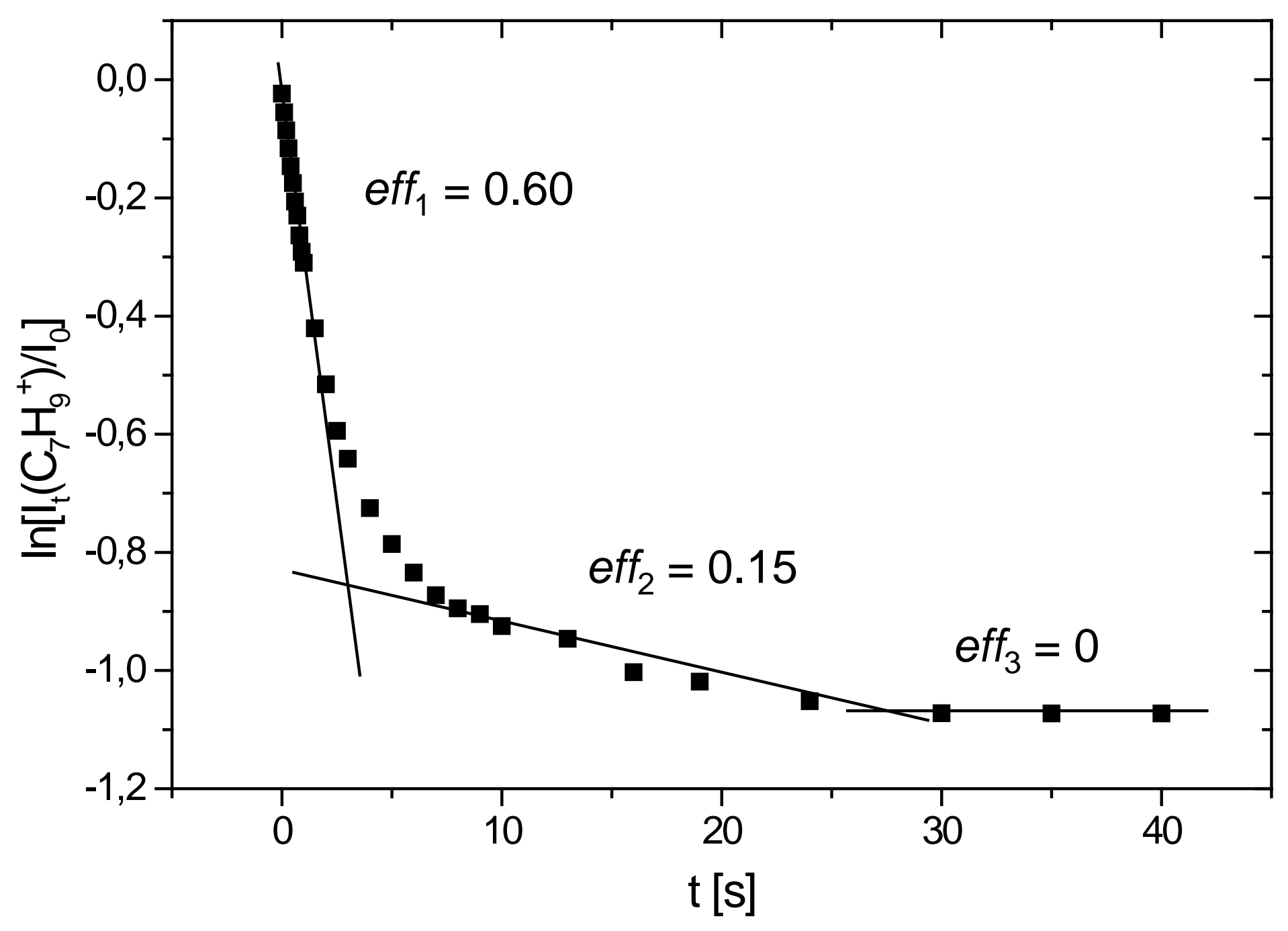

Mormann et al. Figure 5 


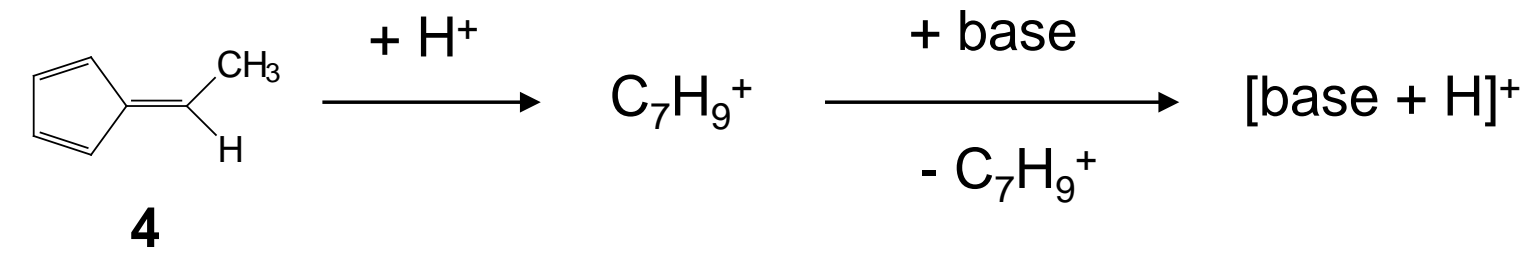

(a) $\mathrm{Cl}$ (methane)

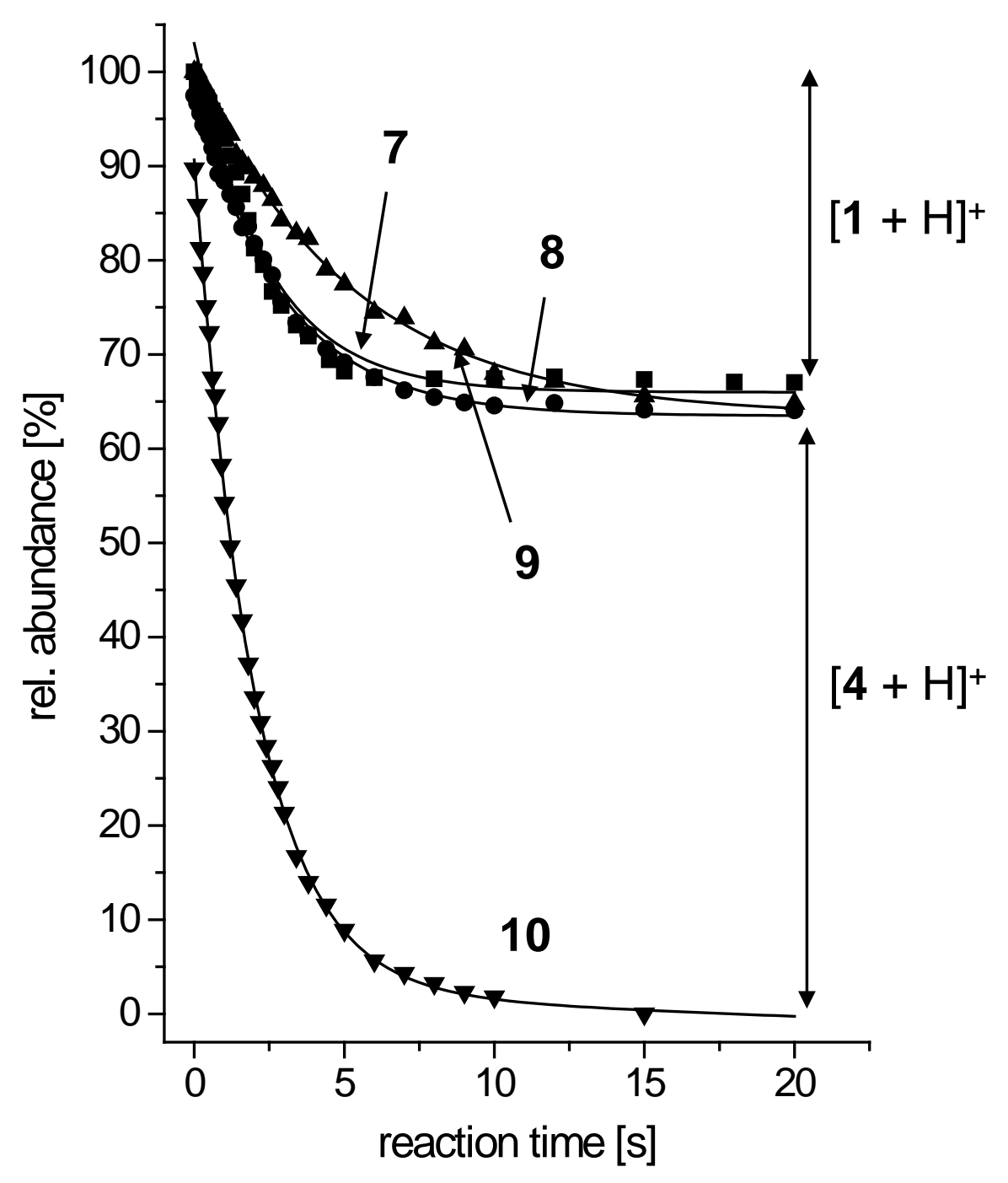

(b) $\mathrm{Cl}$ (isobutane)

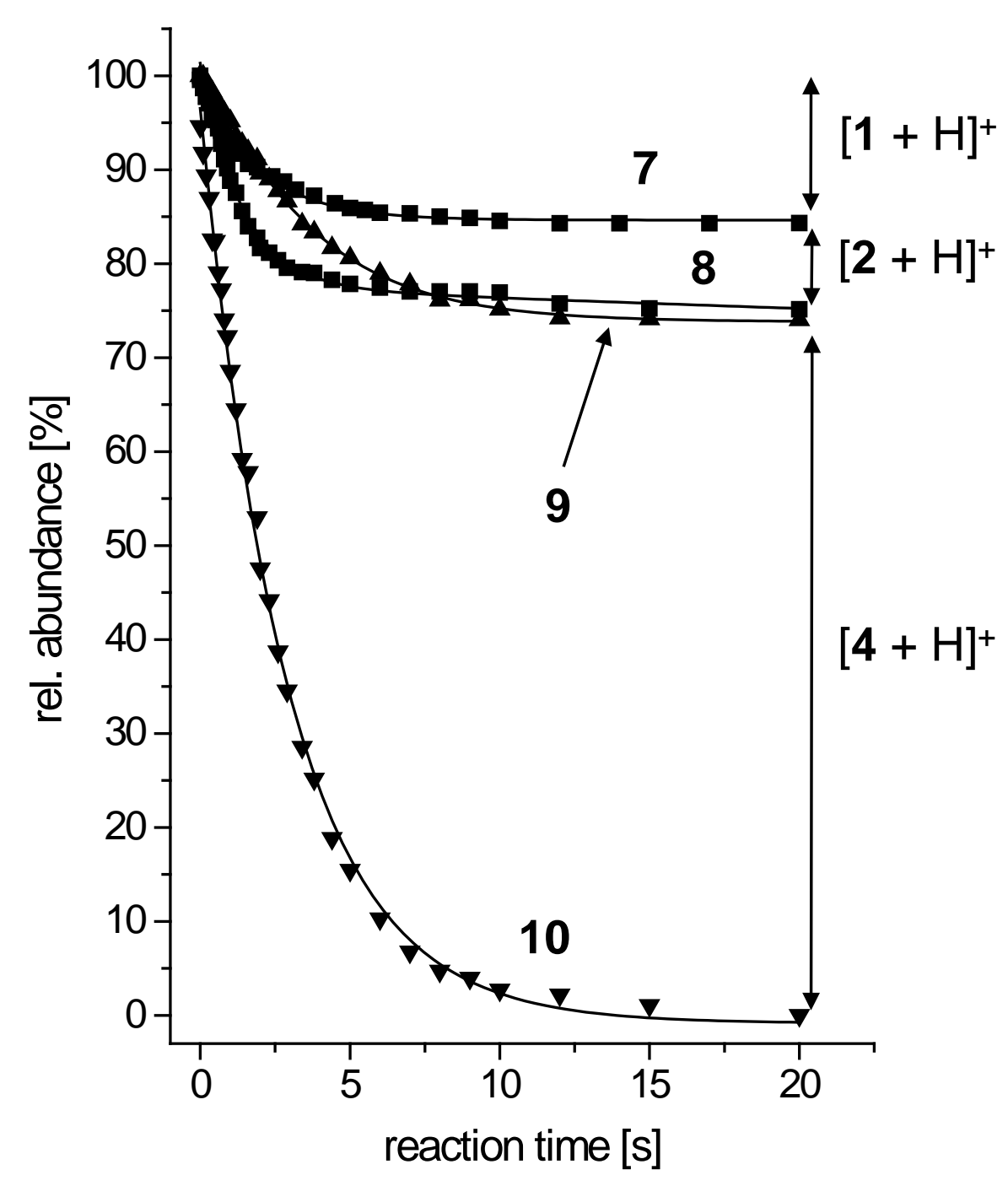




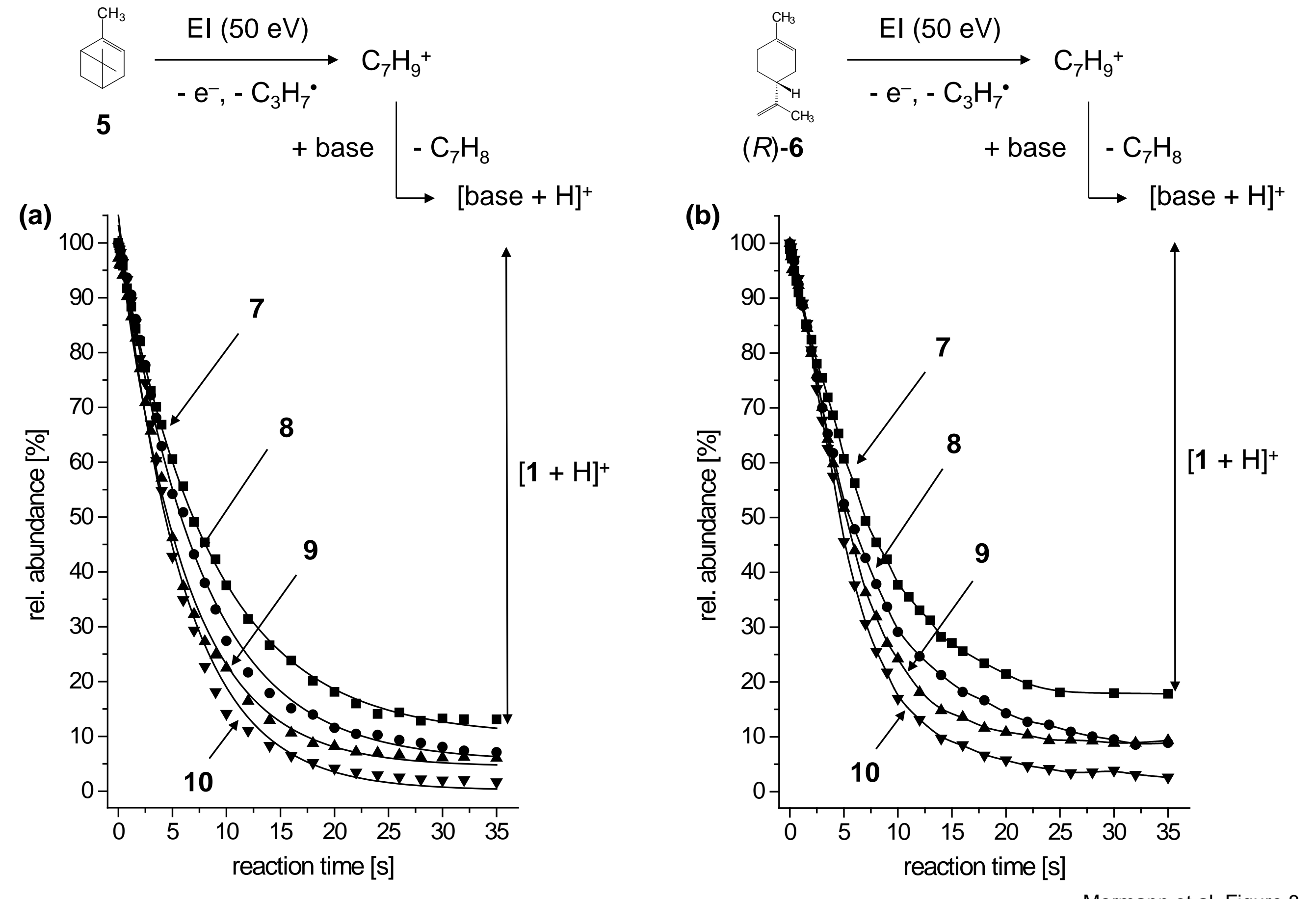




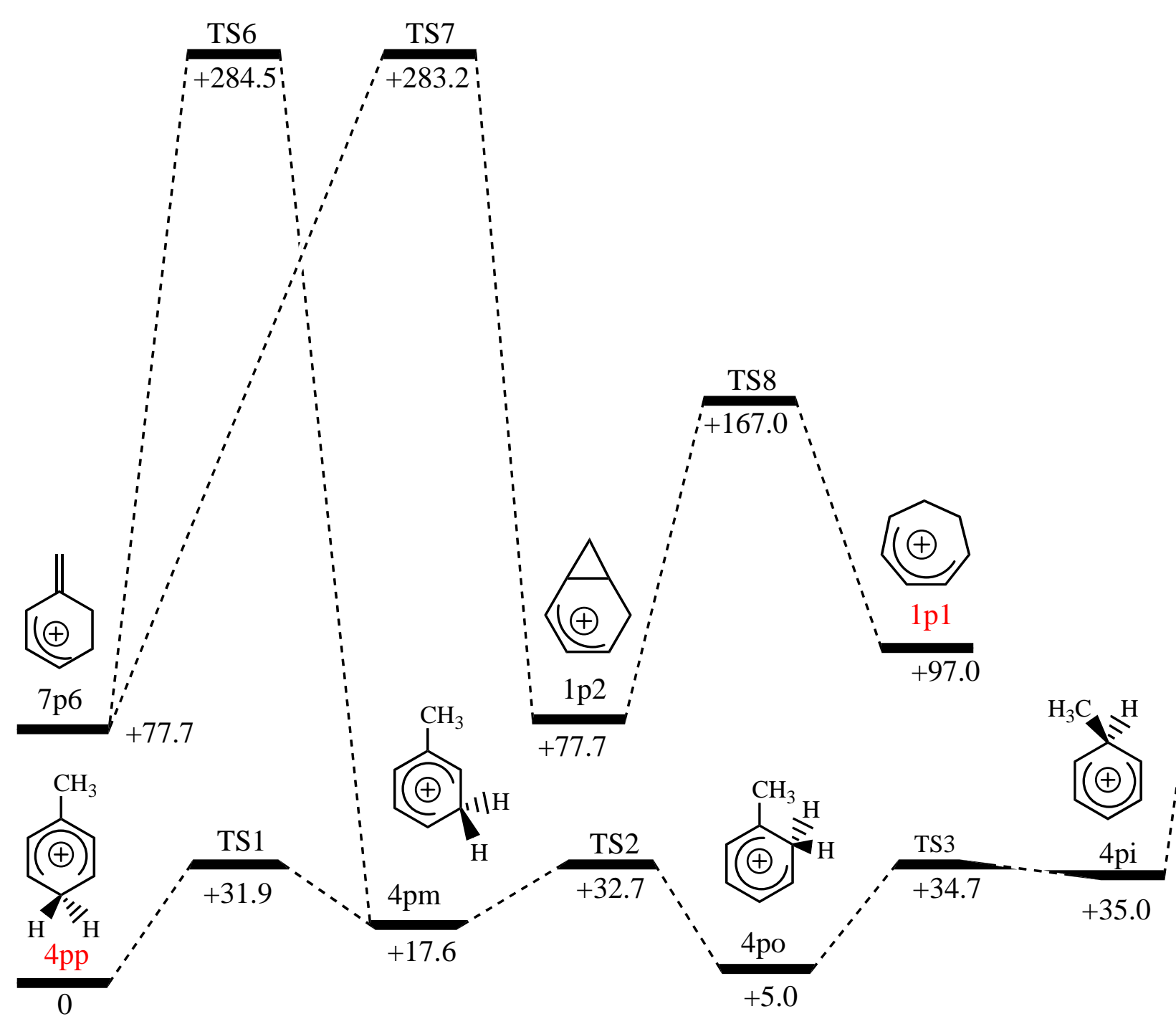

MP2/6-311+G(3df,2p)

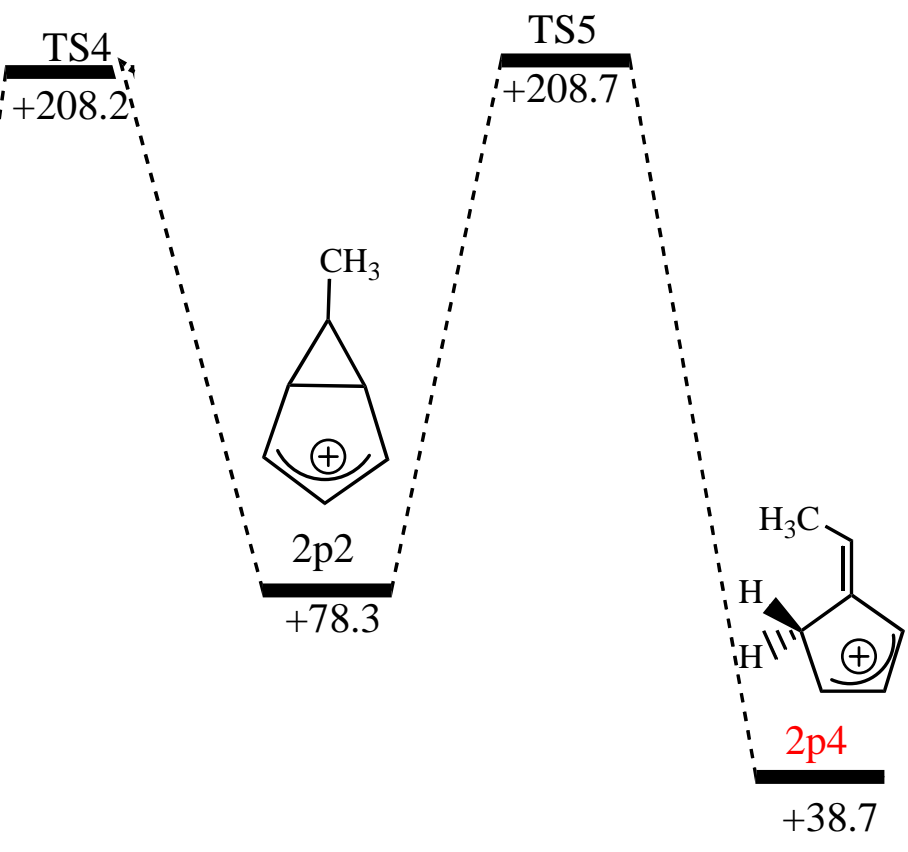

